\title{
The Mosaic Pavements in Philippopolis, Thrace, in 6th c. CE. Some Considerations
}

\author{
Philippopolis, Trakya'daki, İS 6. yüzyı1 Mozaik Döşemeleri. Bazı \\ Düşünceler
}

Ivo TOPALILOV*

(Received 01 January 2020, accepted after revision 14 August 2020)

\begin{abstract}
The present paper deals with the mosaic pavements from Philippopolis which are known so far and that might be attributed to $6^{\text {th }} \mathrm{c}$. CE. The topic is of interest because there is almost no information in the literature about the urban development of the metropolis, although it seems that the city gained huge prosperity especially from the first half to the middle of that century. As part of this prosperity, one should also regard the mosaic pavements that still preserve their importance as a medium of new ideas and religious requirements. The mosaic pavements discussed decorate both public and private buildings and reveal that the specifics of mosaic art in Philippopolis are to be attributed to both official Constantinopolitan initiatives, especially in the liturgical aspect, and also the tastes of local elites, as well as the craftsmanship of the local mosaic workshop. Taken together, these factors led to a variety of iconography, intertwined motifs, and colours, which make some of the mosaics unique so far in Late antique Thrace.
\end{abstract}

Keywords: Philippopolis, Thrace, mosaic pavement, Justinian I, Anastasius I, private residentials, religious buildings.

Öz

Bu makalede, bugüne kadar bilinen IS 6. yüzyıla atfedilebilecek Philippopolis mozaik dössemeleri ele alınmıştır. Konu ilgi çekicidir çünkü literatürde metropolün kentsel gelişimi hakkında neredeyse hiçbir bilgi yoktur. Ancak şehrin özellikle o yüzyılın ilk yarısından ortasına kadar büyük bir refah kazandığ görülmektedir. Bu refahın bir parçası olarak, önemlerini hâlâ koruyan mozaik döşemeler de yeni fikirler ve dini gereksinimlerin birer aracı olarak görülmelidir. Tartışılan mozaik döşemeler hem kamu hem de özel binaları süslemekte ve Philippopolis 'teki mozaik sanatının özelliklerinin hem resmi açıdan Konstantinopolis ile bağlantılı kullanımlara hem de yerel elitlerin zevklerine ve aynı zamanda yerel mozaik atölyelerinin iş̧̧iliğinin ustalı̆̆ına atfedileceğini ortaya koymaktadır. Birlikte ele alındiğında, bu faktörler ikonografi çeşitliliğine, iç içe motiflere ve renklere yol açmıştır, ki bu, mozaiklerin bazılarını şimdiye kadar Antik Trakya'da benzersiz kılar.

Anahtar Kelimeler: Philippopolis, Trakya, mozaik döşeme, I. Iustinianus, I. Anastasius, özel konutlar, dini yapilar.

\footnotetext{
Ivo Topalilov, Institute of Balkan Studies \& Center of Thracology - Bulgarian Academy of Sciences, 13 Moskovska Str., 1000 Sofia, Bulgaria. iD https://orcid.org/0000-0002-0565-2054. E-mail: ivo.topalilov@balkanstudies.bg/itopalilov@yahoo.com
}

This paper was written in the framework of the project LABedia: encyclopedia of Late Antique Balkans, $4^{\text {th }}$ century, financed by the National Science Fund, Contract KH-06-H30/6, 13.12.2018.

My sincere thanks go to Prof. Denver Graninger for proofreading of the text. 
Archaeological excavations that have been conducted in Plovdiv for over a century reveal the splendor and beauty of Roman Philippopolis, known to us from ancient sources, both antique and medieval (Topalilov 2012). At the same time, however, they reveal the splendor and beauty of the late antique city, the metropolis of the province of Thrace. As such, its political, economic, and religious prosperity was ensured. It is no coincidence that archaeological studies show that, despite the many cataclysms that the city experienced during the $4^{\text {th }}$ and $5^{\text {th }} \mathrm{c}$. CE, related to the barbarian invasions of the Goths and Huns, Philippopolis recovered quickly and, in the time of Justinian I, in fact reached the area of its predecessor from the second half of $2^{\text {nd }}-$ the first half of $3^{\text {rd }} \mathrm{c}$. CE, when the city enjoyed its greatest prosperity (Topalilov 2012a: 428-429; Topalilov 2014a: 98-102). Thus, archaeological excavations reveal the existence of quarters extra moenia, which were not attested until that time, despite the city's development as a metropolis located near the new imperial capital of Constantinople. Moreover, the literary sources reveal the great potential of Philippopolis in accommodating the troops of Narzes (Proc. Libri de bellis. VIII. 21) and, later in $601 \mathrm{CE}$, of the western $\tau \alpha \dot{\gamma} \gamma \mu \alpha \tau \alpha$ under the command of Comentiol (Theop. Sim. Hist. VIII. 1-4, 284-291; Theoph. Confess. Chron. 281283) (Topalilov 2014a: 106-107). The archaeological excavations themselves reveal the maintenance, at least until the time of Justinian I, of: the old fortified walls (Bospačieva 2001: 173-183); the Episcopal Basilica, which was the most imposing Christian basilica in Thrace and still awaits its full publication (Kesjakova 1989a: 113-127; Chaneva-Dechevska 1999: 253-254; Kesjakova 2006: 148-149); and the complex of the "Eastern Gate" or Porta Triumphalis, modeled on the Porta aurea in Constantinople (Topalilov 2016b; Topalilov 2020). Excavation has also revealed the construction of a new aqueduct, carrying water from the nearby Rhodope Mountains (Kesjakova 1983: 73), etc. All of this evidence is an indisputable sign of the extraordinary flourishing of the city, which started probably in the time of Anastasius I and lasted until the time of Tiberius Mauritius, when the construction of a new fortress wall reduced the fortified area of the city by almost half. This new wall contains a considerable number of different spolia from earlier, still-standing monuments, some of which were still admired in $12^{\text {th }} \mathrm{c} . \mathrm{CE}$ for their grandiose impression (Anna Comnenae Alexias, Lib. XIV, 8, 296, 11).

In spite of exceptionally strong pagan traditions, it is certain that in the time of Justinian I the main centers of the metropolis were already closely connected with Christianity, with the Christianization of the urban topography already completed by the middle of $5^{\text {th }} \mathrm{c}$. CE; this transformation is apparent: in buildings that appeared ex novo, such as the Episcopal Basilica; in buildings whose purpose was changed accordingly, as was the case with the so-called Domus Eirene that was turned to domus episcopalis in the end of $4^{\text {th }}$ CE (Bospachieva 2003; Pillinger et al. 2016: 174-198; Topalilov 2018); and through the Christianization of significant, existing complexes, of both Roman and Late Antique date, by the construction of specific buildings connected with Christianity, such as the socalled "Eastern Gate" complex. It is logical that these Christian or Christianized complexes were the most imposing in the late antique city and distinguished by their opulent decoration, including the ornate mosaic pavements that in fact characterize late antique Philippopolis. So far, more than 3.000 sq. m. of mosaic floors dating from that period have been discovered (Pillinger et al. 2016: 164270); those dated to $6^{\text {th }} \mathrm{c}$. CE are the main subject of the present study (Fig. 1). 
Figure 1

Late antique Philippopolis. The location of the buildings decorated with mosaic pavements discussed in the text (Episcopal basilica is located under no. 1, Domus Eirene - under No. 2, Residential complex - under No. 3, Conch martyrium - under No. 4, Christian basilica that replaced the Synagogue - under No. 5).

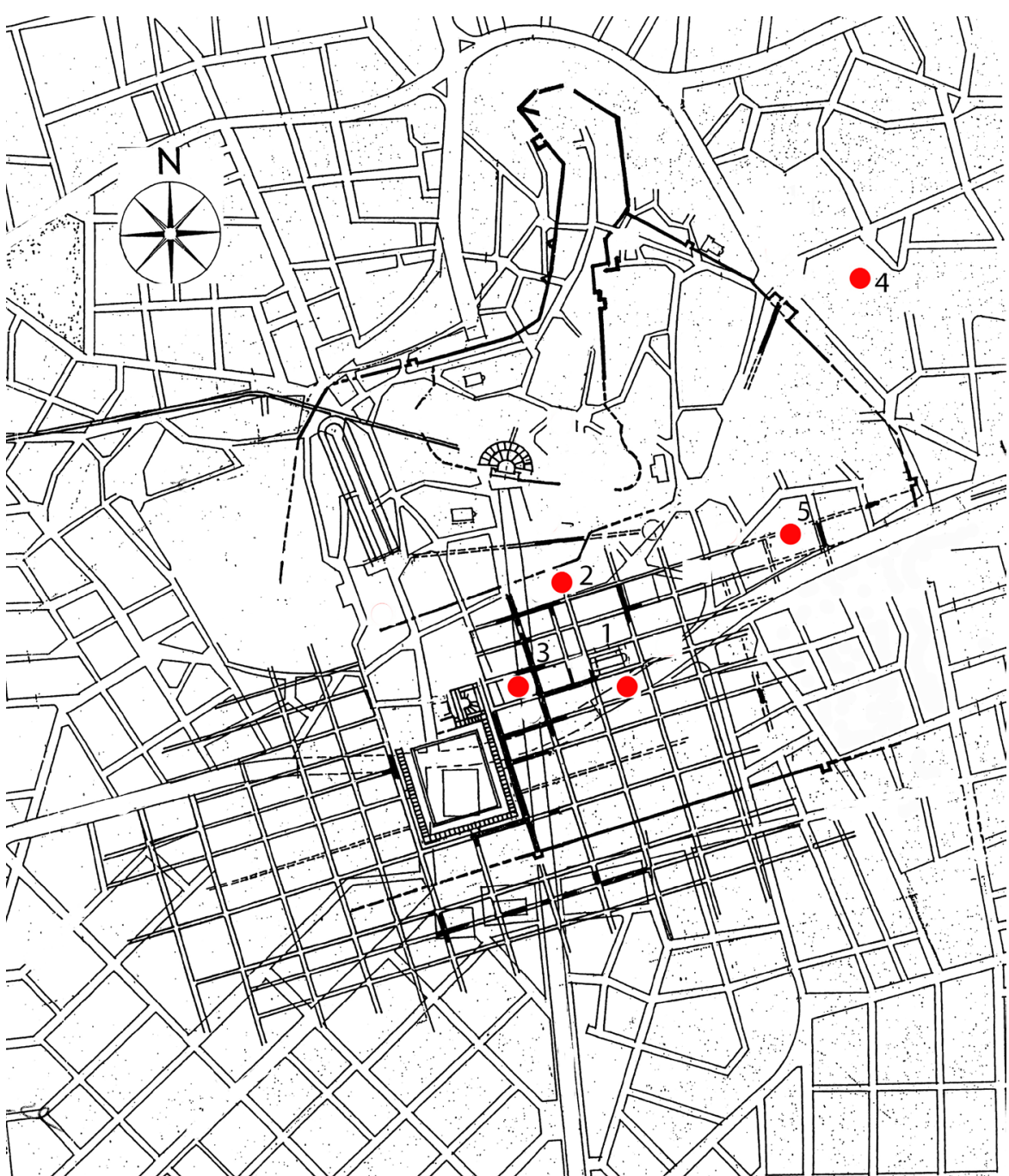

It is well established that in the middle / second half of $4^{\text {th }}$ - the first half of $5^{\text {th }}$ c. CE, a new urban center was formed in Philippopolis, which formed a contrast with the existing pagan center that was located around the agora and the administrative buildings there, and had already become the main principal focus of the metropolis in the second half of the $5^{\text {th }} \mathrm{c}$. CE. It is no coincidence that the agora was abandoned at this time (Dinchev 2009: 63-81). The new center encompassed the Episcopal Basilica, which was built in the second half of $4^{\text {th }} \mathrm{c}$., and the domus episcopalis; the two complexes were connected by a cardo, which was not part of the existing street network. This complex initially appeared as a center of new power, but not yet of the city itself. The latter occurs after joining the "Eastern Gate" with this complex via a monumental street (cardo), whose prototype can be found in Constantinople's Mese (Topalilov 2016: 1856-1858). It is no coincidence that, when the municipal council erected a statue dedicated to Basiliscus, the city's savior, in $471 \mathrm{CE}$, it was not placed in the agora, where one would expect, but within the "Eastern Gate" complex, thus indicating the completion of this process (SGLIBulg, No. 206). It is logical to expect that a large part of the efforts of society and emperors would have been directed precisely to the maintenance and development of this new center. Archaeological excavations prove these expectations.

Let us star our description of the Philippopolis mosaics with those in the Episcopal Basilica (Fig. 1, no. 1). It is highly probable that a certain cataclysm, most probably natural, led to the need to recover the naos with a new mosaic 
floor, much of which has already been published (Kesjakova 2011: 173-210; Pillinger et al. 2016: 198-220; Kantareva- Decheva 2017: 365-372). Initially, its construction was dated to the second quarter of the $5^{\text {th }} \mathrm{c}$. CE (Kesjakova 2011: 193-194), and subsequently in the second half of that century (Popova 2016: 164-165) or even at the end of it - the beginning of $6^{\text {th }} \mathrm{c}$. CE, i.e., during the time of Anastasius I (Pillinger et al. 2016: 220). The mosaic pavement has recently been fully exposed and is still awaiting its full publication, but it is nonetheless possible to make some preliminary observations on already published sections of it in order to establish the date of its construction (Fig. 2). What characterizes

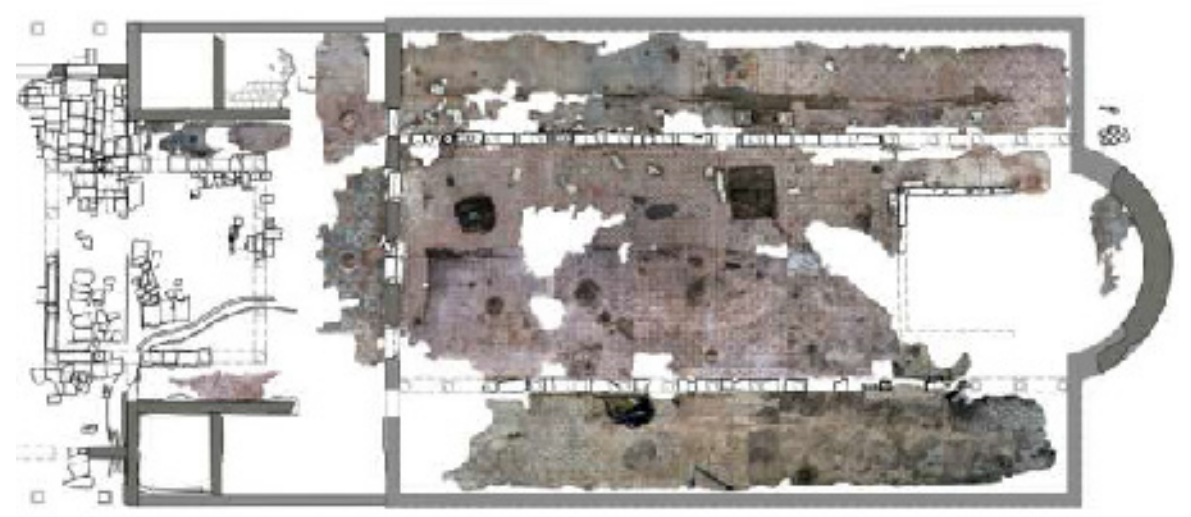

the mosaic floor is the iconographic scheme, concentrated on the outer aisles, with the presentation of the fons vitae image in the southern and the image of a peacock with full feathers in the northern. An identical iconographic scheme is also found in the mosaic floor of the Christian basilica discovered in the capital of the province of Eurōpē, Perinthos (Herakleia) (Westphalen 2016: 86-110), which clearly indicates that the decoration of both basilicas was a product of the same conception that probably encompassed the Episcopal basilicas located in the hinterland of Constantinople. The construction of the Christian basilica in Heracleia dates back to 450-480 CE (Westphalen 2016: 27-115), which may suggest also the date of the new mosaic pavement of the Episcopal Basilica in Philippopolis. The latter has a clear terminus ante quem of $476 \mathrm{CE}$, when the construction of the so-called "Small Basilica" in the city at latest was dated, and whose mosaic floor differs significantly in quality, iconography, and style (Bospachieva 2002: 55-76; Pillinger et al. 2016: 227-238). This means that redecoration of the Episcopal Basilica in Philippopolis and hence the construction and decoration of that in Heracleia should be dated to 50's-60's of $5^{\text {th }} \mathrm{c}$. CE, when it seems that a special initiative was taken. In Philippopolis the mosaic pavement was replaced by a new one, while the basilica in Heracleia, which was built at that time, received identical pavement decoration. The latter construction followed architecturally a new metropolitan basilican type of building with established dimensions and polygonal apse that soon spread in Thrace. It should be emphasized that the catholicon of the Studios monastery at Constantinople was also built according to this unknown yet prototype. Stylistically, the mosaics can also refer to the third quarter of $5^{\text {th }} \mathrm{c}$. CE, rather than to the beginning of $6^{\text {th }}$ c. CE (Popova 2016: 165).

This does not mean, however, that we cannot find a mosaic panel dated to $6^{\text {th }} \mathrm{c}$. $\mathrm{CE}$ in the nave of the Episcopal Basilica in Philippopolis. Thus, it seems that the construction of the first panel of the central nave, which is radically different in
Figure 2

The upper mosaic pavement of the Episcopal basilica fully uncovered (after Kantareva 2017: 367 fig. 1). 


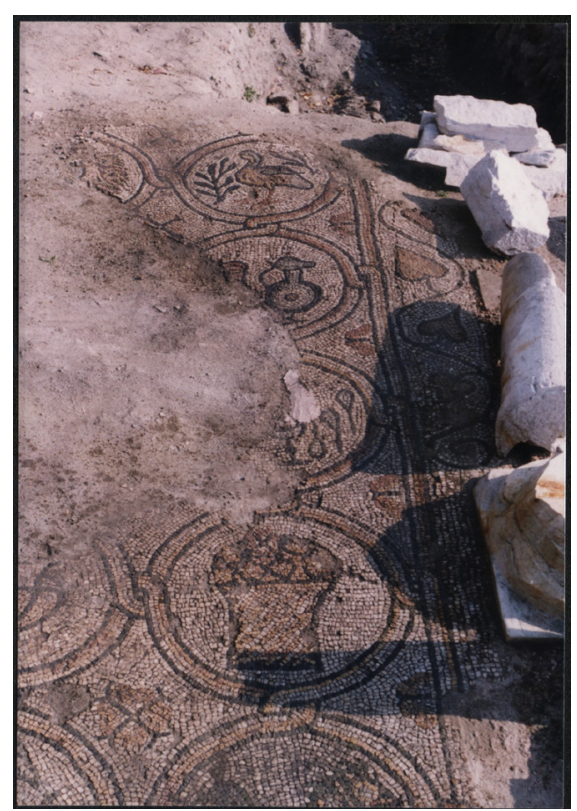

Figure 3

The first panel of the nave in the Episcopal basilica (after Pillinger et al. 2016: Taf. 146 Abb. 380).
Figure 4 A detail of the panel (after Pillinger et al. 2016: Taf. 147 Abb. 381) style and subject matter from the others, may be more likely assigned to $6^{\text {th }} \mathrm{c}$. CE than earlier; it has been dated to the time of either Justin I or Justinian I in the recent bibliography (Pillinger et al. 2016: 217; Kantareva-Decheva 2017: 371). The panel is filled with polychrome circles looped together tangentially, which form circle medallions and irregular concave octagons (Décor I: pl. 235a); the former are filled with birds, baskets with flowers, cantharos, jug, chalice and spoons (?) (Figs. 3-5), the latter with stylized rosettes. Although the range of colours used is simple when compared with the other mosaic panels, the panel is vivid and nuanced, with near three-dimensional presentation of the birds and objects. The limited range of images shows that they were chosen deliberately and in fact might be linked to the Eucharistic ritual.

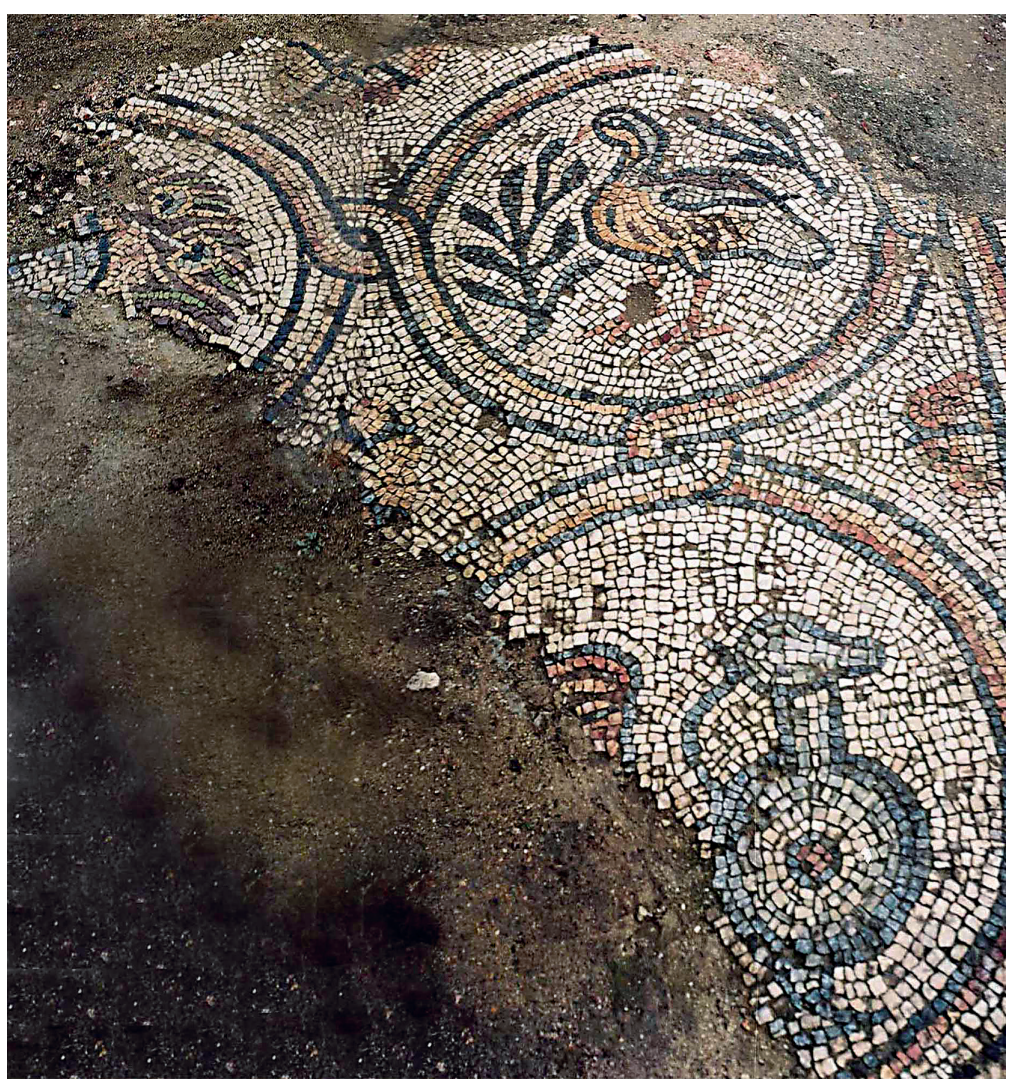

Figure 5 A detail of the panel (archive of E. Kesjakova).

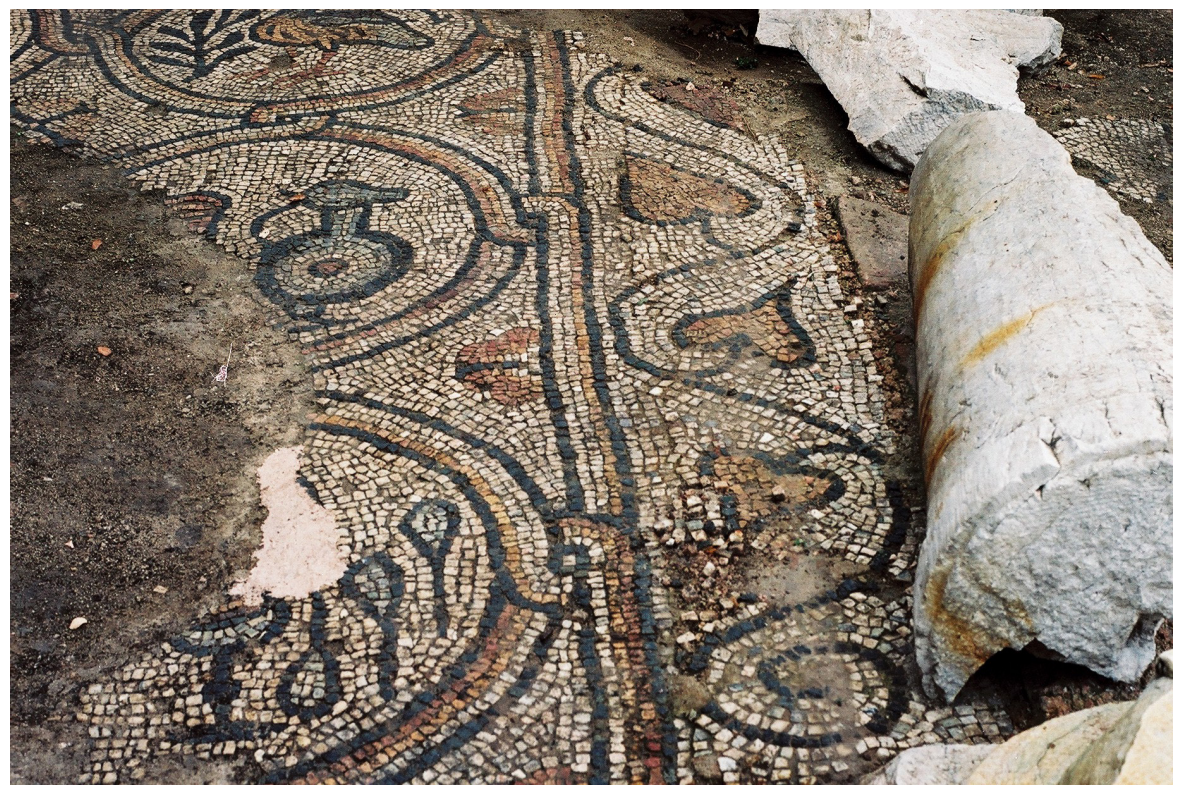


Of interest are the grounds for the change of the eastern-most panel into the nave. Indeed, in the last publication, the laying of the panel is presented as part of the overall renovation of the naos floor decoration, but the different stylistic features, as well as the colour range and techniques used, are an indication of a certain asynchrony. Why was this new panel produced? Was it a change of the decoration, or just a "patch" as suggested?

A clue may be found in the latest archaeological excavation, which shows that it was not just that panel that was changed, but also the space north and south of the presbyterium (Kantareva-Decheva 2017: 371-372). Unfortunately, we do not yet know how the new panels on both sides of the presbyterium were decorated, as they are not published yet, but one may reasonably suggest that the whole space around the altar received new mosaic decoration deliberately and with purpose. The features of the first panel into the nave, which represent a clear link between this space and the Eucharistic liturgy with the motifs in the circles, suggest as much. I would not be surprised if the whole space around the altar was in fact redecorated in order to create a new liturgical ritual place and alternative to the existing one in the middle of the south aisle with fons vitae scene. If we develop further this hypothesis, we might expect that the liturgical change reflected by the mosaic pavement decoration was inspired by Constantinople, as it was almost a century earlier, in the third quarter of $5^{\text {th }} \mathrm{c}$. CE (Topalilov 2019; see also Popova 2016: 172-175 on the link between the liturgy and the mosaic pavement decoration). If so, the change should be very likely dated to the time of Justinian I when the liturgical changes are attested, which was also reflected in the mosaic art.

The Episcopal Basilica, however, is not the only Christian building in Philippopolis with mosaic pavement redecorated in $6^{\text {th }} \mathrm{c}$. CE.

Another building that is accepted to have received a new mosaic floor decoration in $6^{\text {th }} \mathrm{c}$. CE is the Christian church that replaced the ancient synagogue (Fig. 1, no 5)(Kesjakova 1989: 20-33). The floor decoration of this new building was completely geometric and, although fragmentary, it is possible to reconstruct its iconography (Fig. 6). According to the fragments, the border consists of opposing, heart-shaped leaves, after which follows the frame of the inner panel. The latter is filled with an orthogonal pattern of eight-pointed stars with lozenges and octagons with four-pointed stars in medallions (Décor I: pl. 178d). All parts and elements are filled with geometric motifs, among which one finds swastika panels with a centrally inscribed Solomon knot, braided ribbon motifs (braided square with loops and circular ribbon weave), rosettes with four heart-shaped leaves, and objects in the form of silver plates etc. The mosaic has a particularly extensive colour scale, with white, yellow, green, brown, red, and black tesserae, some of them made of sandstone and terracotta (Figs. 7-11). In the course of partial repairs, several damaged motifs were restored by individual marble and brick slabs (Pillinger et al. 2016: 245).

As mentioned, the mosaic is to be closely associated with the transformation of the plan and interior of the earlier Synagogue. Some dates are proposed for the building transformation and the construction of the mosaic pavement.

It is suggested that the new mosaic pavement and, therefore, the architectural transformation itself is dated to late 4 th - first half of $5^{\text {th }} \mathrm{c}$. CE (Pillinger et al. 2016: 247). E. Kesjakova, however, divides both events as she is inclined to date the architectural transformation to the beginning of the $5^{\text {th }} \mathrm{c}$. CE, when she believes the Jewish community was persecuted, while this new Christian building was decorated with mosaic pavement in the middle of $5^{\text {th }}$ c. CE (Kesjakova 1989: 
Figure 6

Reconstruction of the mosaic pavement

of the Christian temple that replaced the synagogue (after Pillinger et al. 2016: Taf. 174 Abb. 449).

Figures 7 - 8

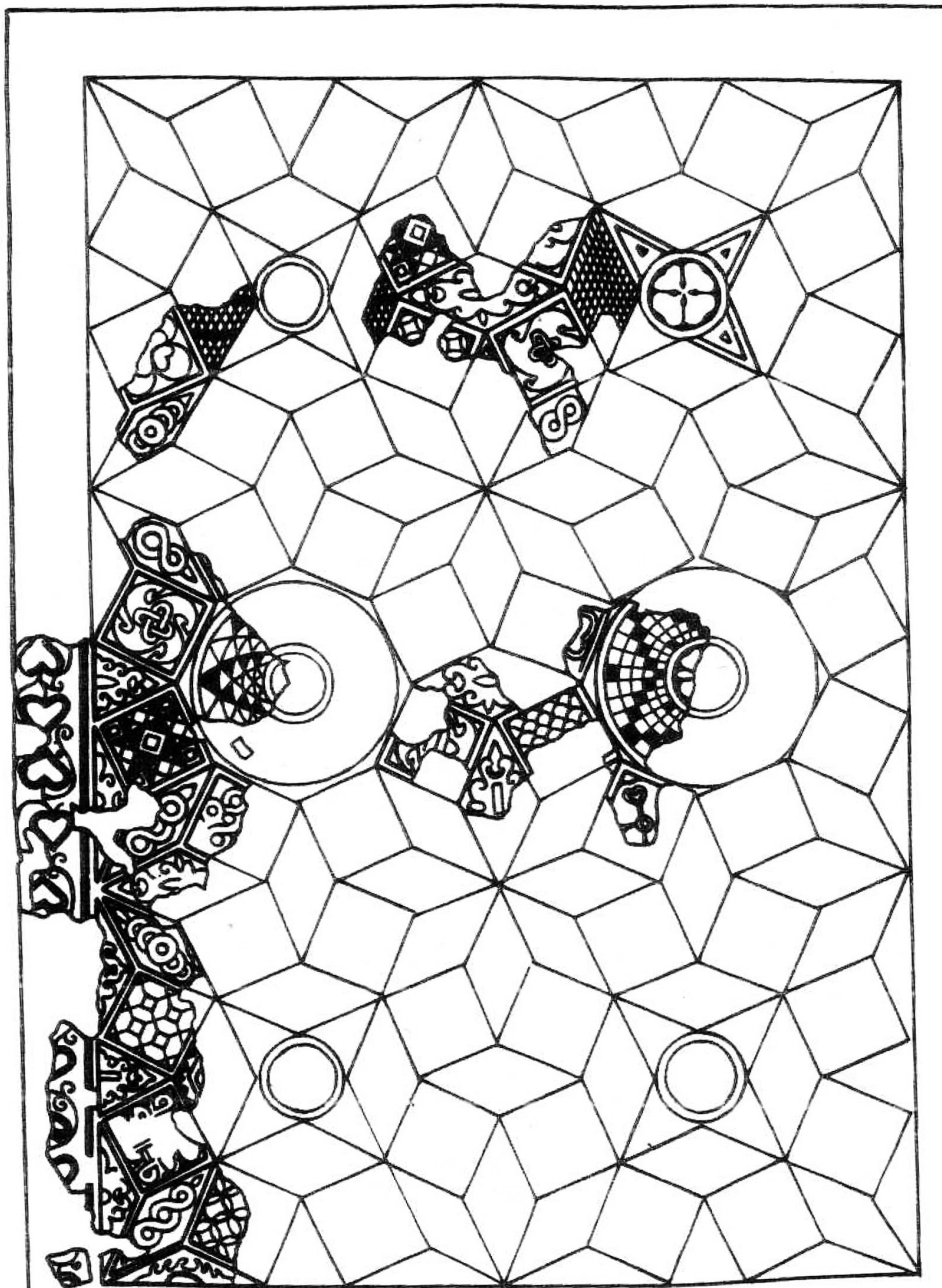

Fragments of the mosaic pavement (archive of E. Kessjakova).
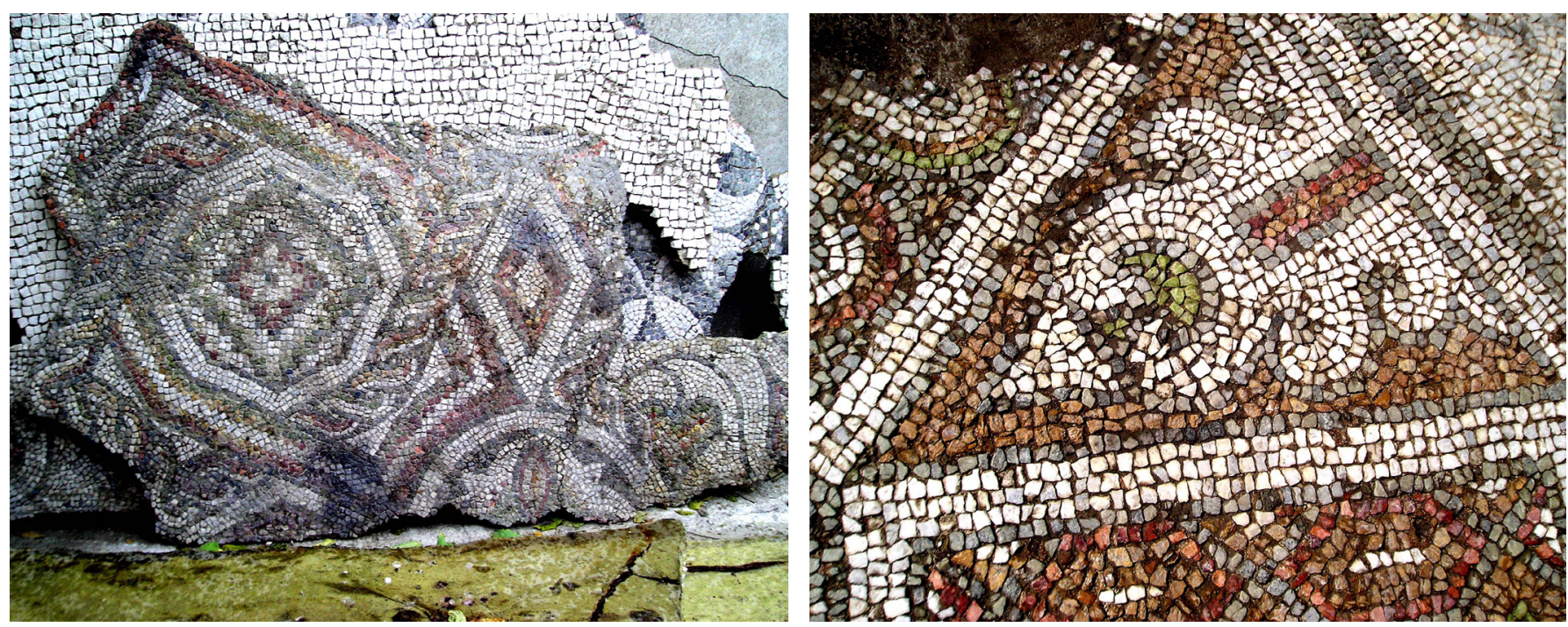

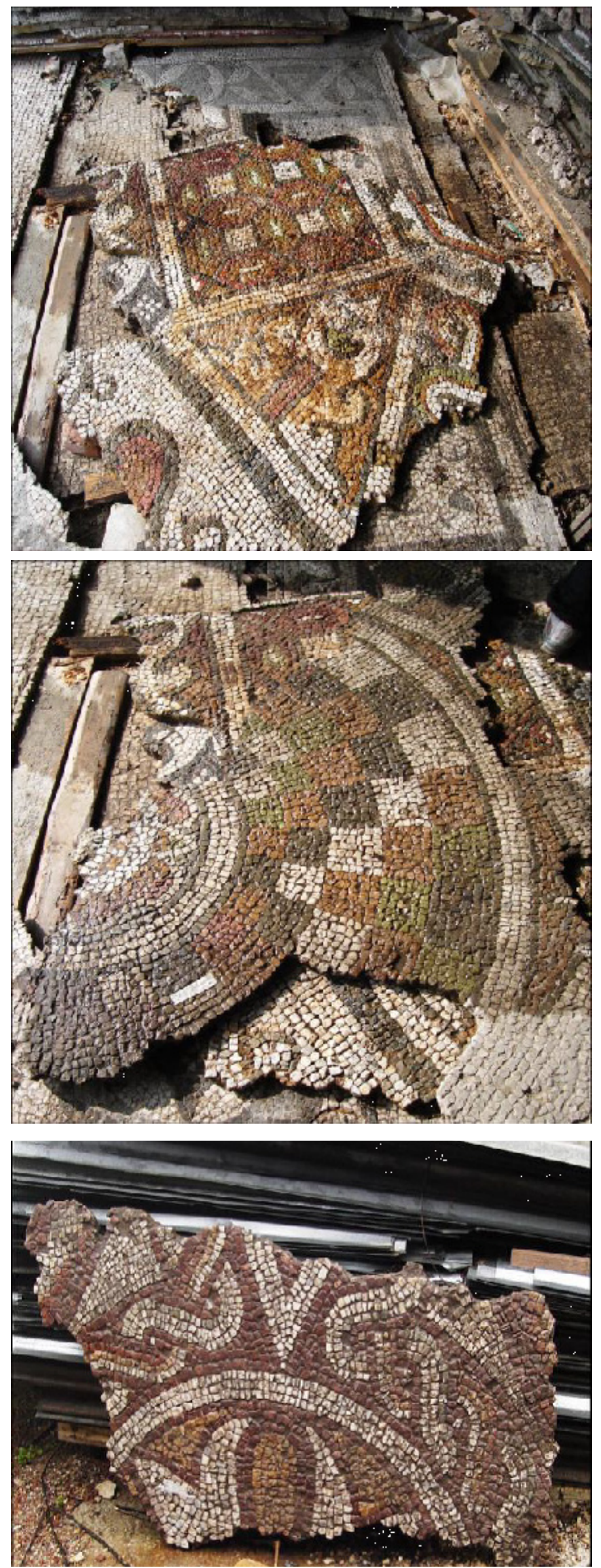

Figures 9-10-11

Fragments of the mosaic pavement

(after Bospachieva - Kolarova 2014:

272). 
31). R. Kolarik has argued that both activities should be dated to the end of $5^{\text {th }}$ - beginning of $6^{\text {th }} \mathrm{c}$. CE (Kolarik 2014: 122, 127-128), i.e., in the time of Anastasius I. The latter date seems to me more plausible due to both historical circumstances and archaeological context.

Indeed, while some synagogues seems to have suffered since the time of Arcadius, as shown in Cod.Theod. 16.8.9, they were not converted into Christian churches, but destroyed. In $423 \mathrm{CE}$, however, the attitude changed in the Praefectura Oriens, where Philippopolis was located, and, in some places, the Jewish temples might have been turned into Christian ones (Cod.Theod. 16.8 .21 ; 16.8.26). Such transformations might have occurred mainly in those places where the synagogues were abandoned after the Jewish community had vanished for various reasons. Otherwise, the community would receive at least a new place for a new temple as described in the edict. But Philippopolis seems not to be one of those cases.

The situation might have changed after 40 's of $5^{\text {th }} \mathrm{c}$. CE when the Hunnic invasions made a great impact on the urban development of the city. Philippopolis began to lose its ancient appearance and many antique complexes, including the agora, were abandoned. We have no evidence of the Jewish community of that time, but, even if it suffered and disappeared, the transformation of the synagogue should have taken place some decades later, when the city was restored. Excavations have revealed the use of some marble spolia, bonded with white mortar and pieces of bricks, in construction associated with the Christian reuse of the synagogue (Kesjakova 1989: 29), which may in turn suggest that this building took place after Philippopolis had lost some of its antique buildings and complexes. A date of the last quarter of $5^{\text {th }}-$ beginning of $6^{\text {th }} \mathrm{c}$. CE is also in line with other examples from the Balkans, such as the synagogue in Stobi, for instance, that was replaced by a Christian basilica (Kolarik 2014: 119). In the second half of $5^{\text {th }} \mathrm{c}$. CE, the Episcopal Basilica of Philippopolis was embellished with new mosaic pavements full of figural motifs, which is in sharp contrast to our mosaic. The mosaic decoration of the so-called "Small basilica", built in $471 \mathrm{CE}$ in Philippopolis, offers a closer parallel, however, with its lack of figural motifs, but distinctive colours and iconography. So, I would prefer to date the mosaic pavement of the new Christian building to Anastasian or pre-Justinianic date rather than earlier, having in mind the prevalence of ornamental-geometric motifs, the crude manner and technique of the mosaic, the large tesserae, as well as the use of spolia in the constructions, a practice that gained wide acceptance in the second half of $3^{\text {rd }} \mathrm{c}$. CE as well as in $6^{\text {th }} \mathrm{c}$. CE. Some iconographic motifs, in fact, are to be found only in mosaics dated to $6^{\text {th }} \mathrm{c}$. CE, and not in those of second half of $5^{\text {th }} \mathrm{c}$. CE; a good example of this tendency is the border of the new mosaic.

A similar case to that in the Episcopal Basilica is the case with the conch martyrium that was a part of the "Eastern gate" complex of Philippopolis (Fig. 1, no. 4). Despite the partial study of the building, which has left significant questions unresolved, including its construction date, scholars believe that it was constructed "in the time of Constantine I or after" (Bospatchieva 2001: 66). Recently, however, a later date has been proposed - end of $4^{\text {th }}$ - beginning of $5^{\text {th }}$ c. CE (Topalilov - Ljubenova 2010: 67-69). During the second period of its existence, the building received mosaic pavement decoration (Bospachieva - Kolarova 2014: 280; Pillinger et al. 2016: 257-263). Although fragmentarily preserved (Figs. 12-13), it is clear that it consists of a wide border (greater than $0,70 \mathrm{~m}$ across) filled with the geometric scheme already known from the nave 


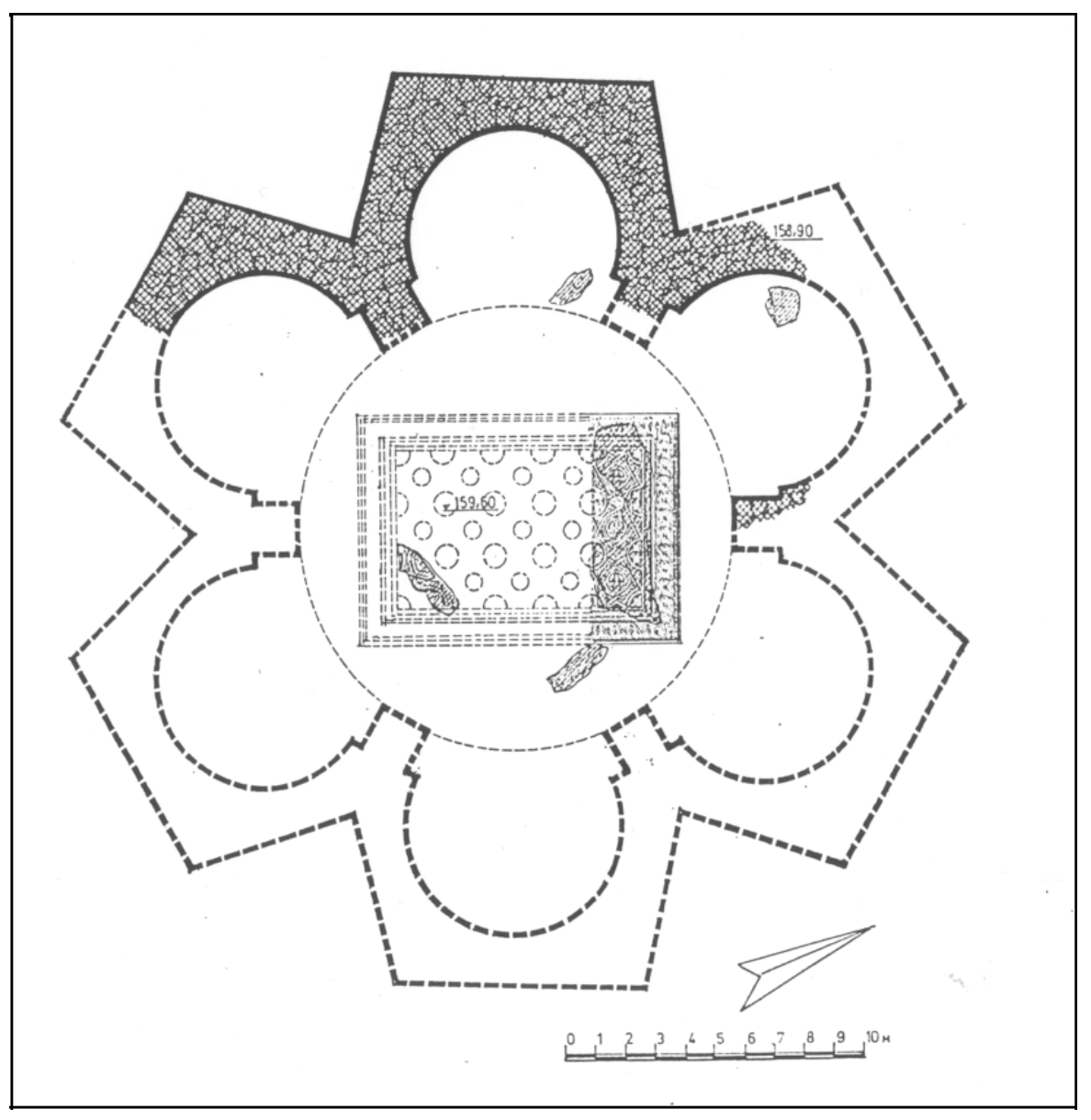

Figure 12

The preserved mosaic floor at the conch martyrium (after Pillinger et al. 2016: Taf. 185 Abb. 476).

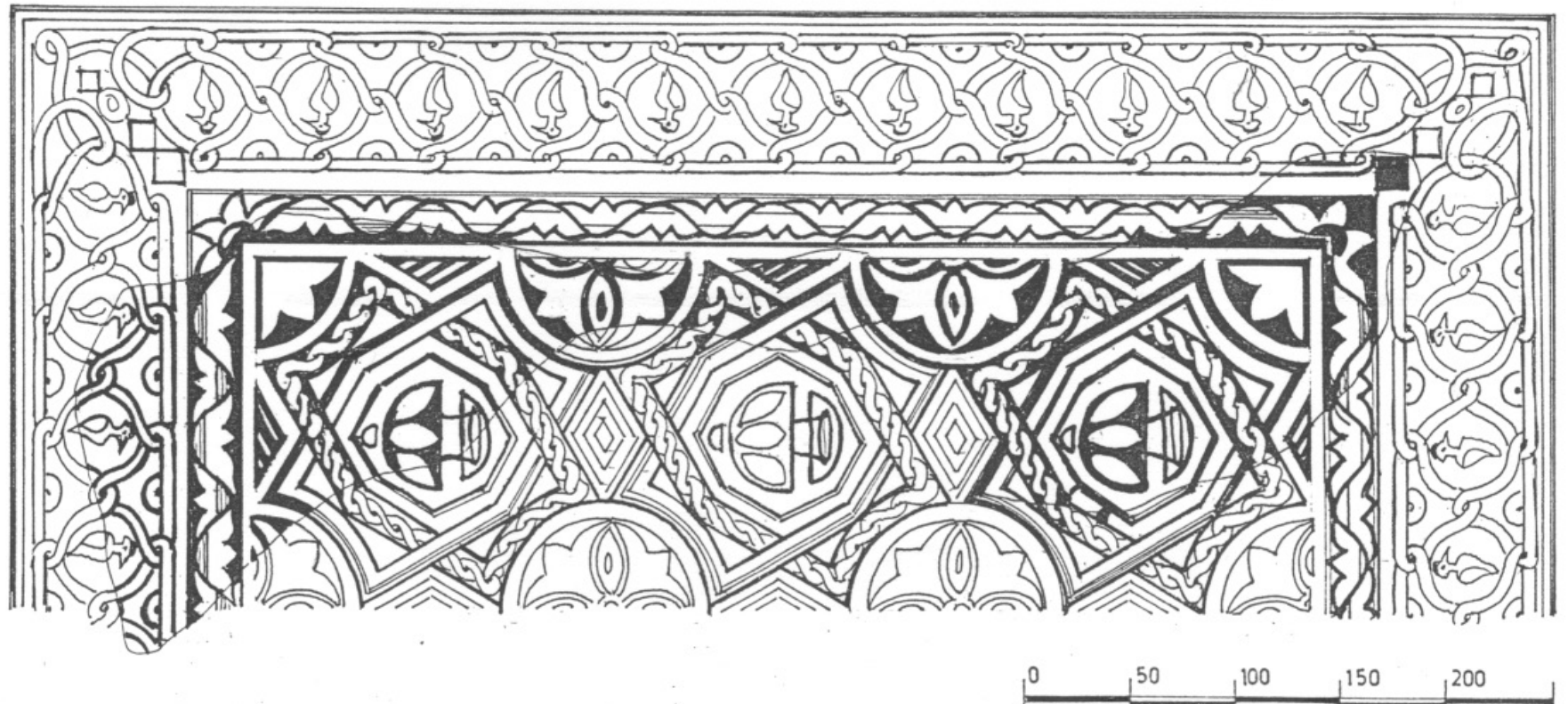

of the Episcopal Basilica: polychrome circles looped together tangentially and forming circle medallions and irregular concave octagons, the former filled with birds, the latter with stylized rosettes (Décor I: pl. 235a) (Fig. 14). The colours used are diverse: black, white, yellow, gray, red, and ochre.

Figure 13

The preserved part of the mosaic floor of the conch martyrium (after Pillinger et al. 2016: Taf. 186 Abb. 477). 
Figure 14

The preserved part of the bordure of the mosaic floor of the conch martyrium (archive of M. Bospachieva).

Figure 15

The preserved part of the mosaic floor of the conch martyrium (after Pillinger et al. 2016: taf. 186 abb. 479).

Figure 16

The preserved part of the mosaic floor of the conch martyrium (after Pillinger et al. 2016: taf. 186 Abb. 481).

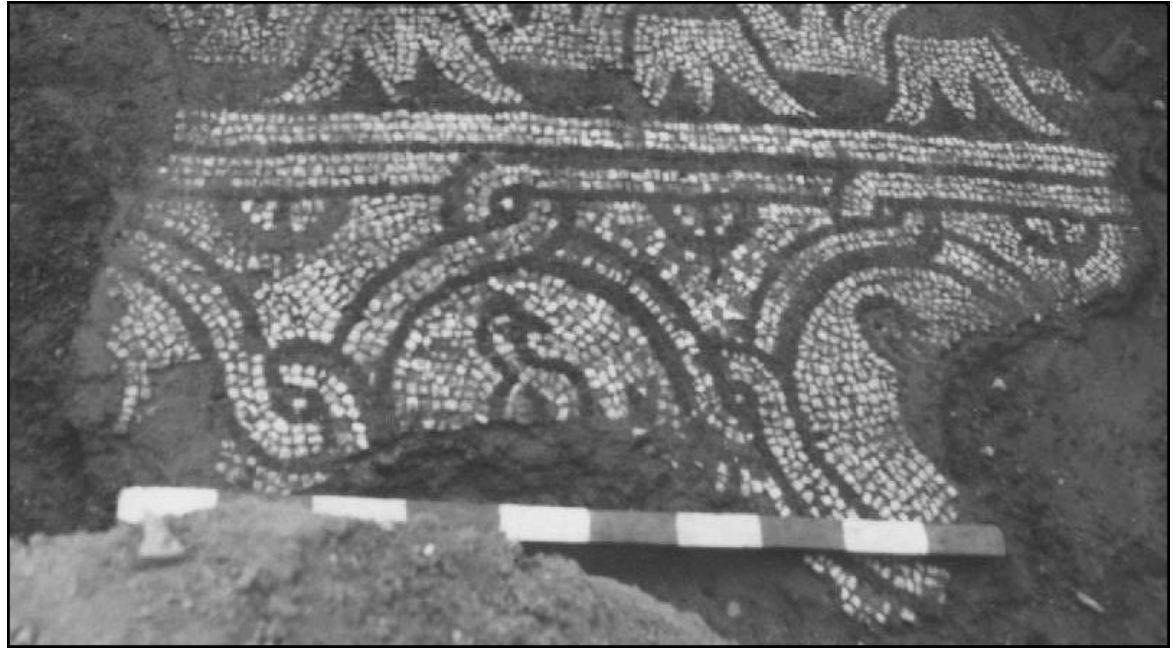

A second, smaller border with lotuses is placed within this first, wide border, followed by the mosaic itself, which consists of the conventional scheme of interlaced scuta (shields), where the resulting octagonal fields are filled with cantharos and the rest with developed rosettes (Décor I: pl. 153a) (Figs. 1516). The colours used are comparatively less expressive than those used for the border and consist of black, red, and white tesserae.
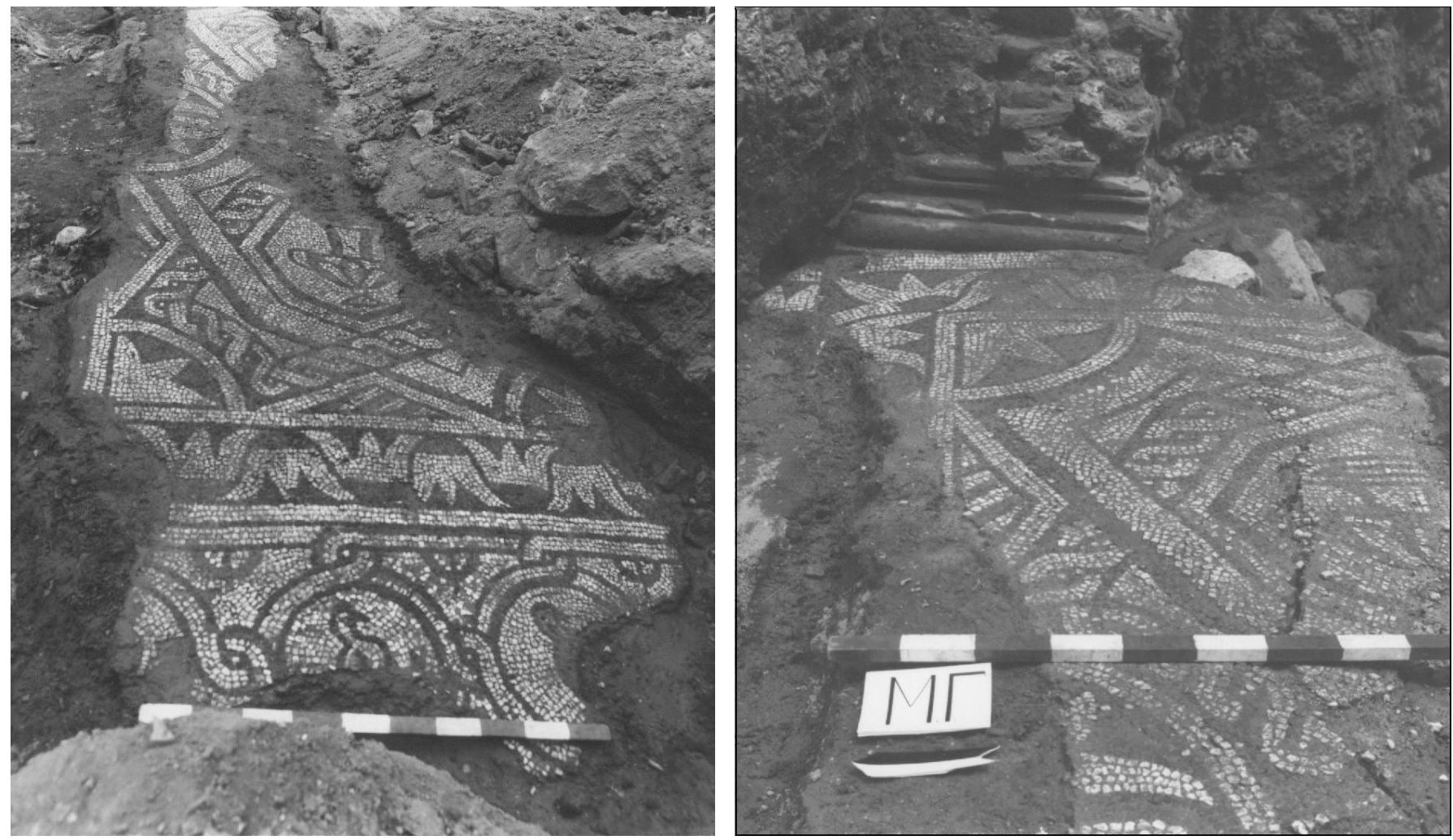

Bearing in mind that the martyrium was restored in the second half of $5^{\text {th }} \mathrm{c} . \mathrm{CE}$, it is logical to assume that the building received its mosaic pavement decoration in the second half of $5^{\text {th }} \mathrm{c}$. CE or beginning of 6th c. CE (Bospachieva - Kolarova 2014: 280). But the juxtaposition of colours between the border and inner panel, in which the former is more colourfully diverse, is more characteristic of the mosaics of $6^{\text {th }} \mathrm{c}$. CE and unusual for those of the second half of $5^{\text {th }} \mathrm{c}$. CE. Besides, the representation of the scheme of interlaced scuta in the other 
mosaics in Philippopolis, dating from the second half of $5^{\text {th }} \mathrm{c}$. CE, is different in the colour range used. All this suggest a later date than proposed previously for the mosaic, namely - to $6^{\text {th }} \mathrm{c}$. CE (Pillinger et al. 2016: 263). Comparison with other mosaics from Philippopolis may help to further refine this date.

It is noteworthy, for example, that the mosaic decoration of the new Christian basilica that replaced the old synagogue, which, as I have argued, took place at the end of $5^{\text {th }}$ - beginning of $6^{\text {th }} \mathrm{c}$. CE, is entirely geometric, in the central medallions as well as the additional fields. And this is in contrast to the mosaic in the martyrium, despite the prevailing geometric pattern of the latter. Moreover, we have observed the colour contrast between them, with vibrant colours used in the Christian temple and the spare use of colour in the martyrium mosaic despite the more colourful border. This may be an argument that these two public Christian buildings are not contemporary and that the mosaic pavement in the martyrium is later than that of the Christian temple.

Another terminus post quem for the martyrium mosaic may be found in the mosaic pavement that decorated the presbyterium of the Episcopal Basilica of Philippopolis. The dichotomy here between the border and inner field is not to be observed, with more diverse colours and images of birds that are not that stylized. It seems that, although close in liturgical aspect, which may explain the resemblance of both mosaics in some features, the mosaic that decorated the martyrium is following a different trend. In fact, it seems that the mosaic in the martyrium is the latest of all, and the juxtaposition between border and panel is not typical of the mosaic art in Philippopolis in $6^{\text {th }} \mathrm{c}$. CE. Therefore, it would not be surprising if the martyrium received its mosaic floor in the middle of $6^{\text {th }}$ c. CE, i.e., during the time of Justinian I, a certain period after the changes made in the Episcopal Basilica, as the new mosaic pavement took into account the liturgical specifics that affected the Episcopal Basilica.

Before turning to the decoration of private houses, it is necessary to pay attention to another monument of the period under consideration, which also relates to Christianity. This monument, probably a tomb, is oriented east-west ( $3 \mathrm{x} 1$, $45 \mathrm{~m}$ ) and decorated with a mosaic floor, which consists of concave octagons and circle medallions. The former is filled with quatrefoils and an unknown irregular, cube-shaped object (Fig. 17), the latter with a crater and a bird (Fig. 18). The colors used are light green, pink, yellow, white, and reddish purple. The
Figure 17

Fragments of the mosaic floor of the tomb (after Dyakovich 1906/1907: 6-8 figs. 3-5).
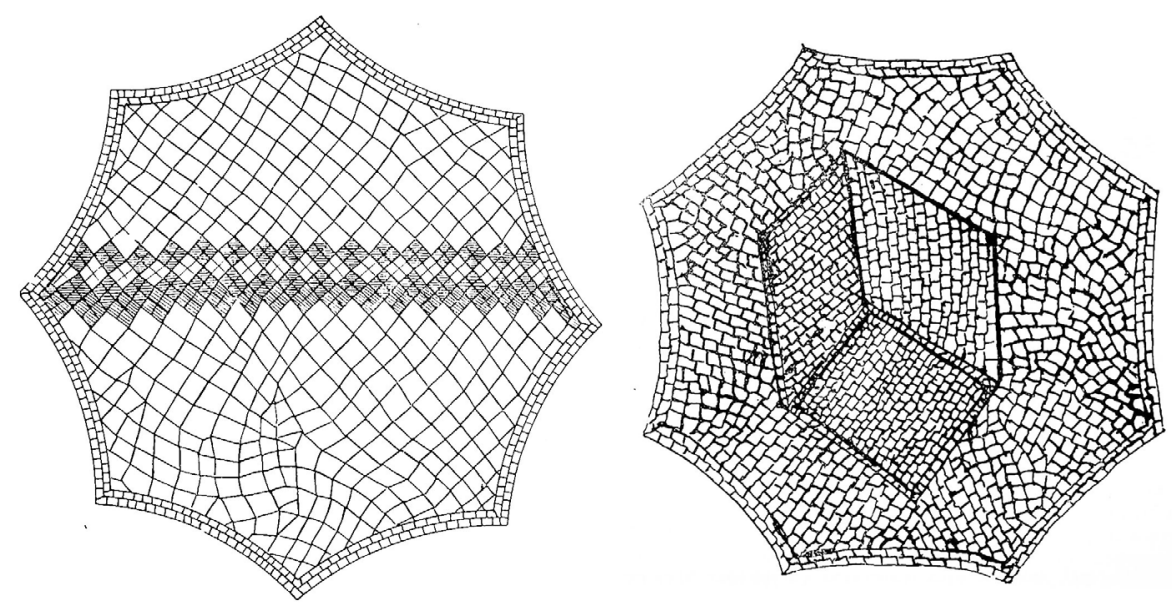

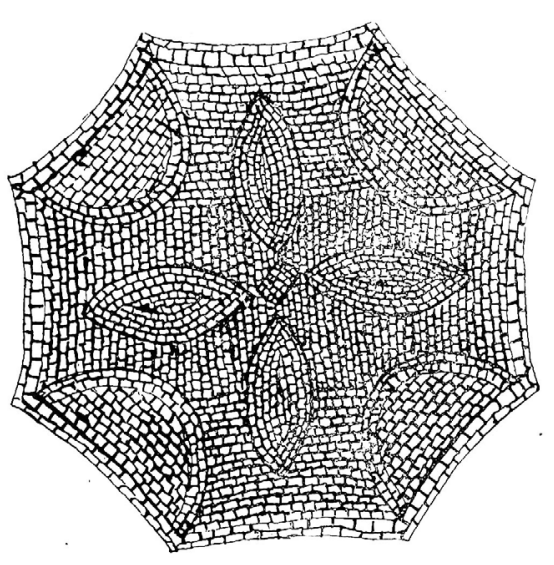



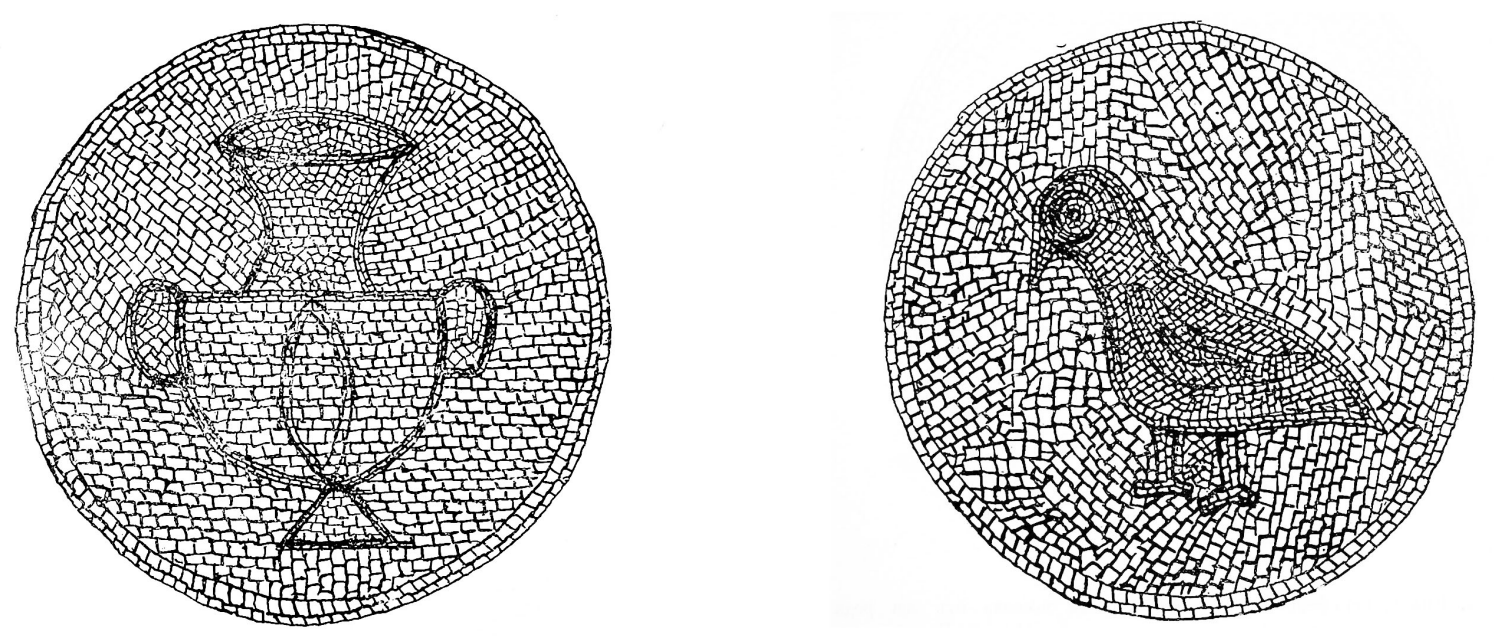

Figure 18

Fragments of the mosaic floor of the tomb (after Dyakovich 1906/1907: 9-10 figs. 6-7). tesserae are irregular, bigger than the usual size. In the case with the irregular cubic object, unlike the rest of the images the background is in dark colours (Dyakovich 1906/1907: 5-11). The main motifs, while carefully made, are schematic and in some cases in inappropriate size. The mosaic is closer to that which decorated the so-called "apodyterium" of the residential complex west of the Episcopal basilica that will be discussed below.

As already mentioned, private buildings also give us the opportunity to explore the issues presented here. I will focus on two cases: in the first, there was an intervention within the repair of a sector of an existing mosaic floor; in the second, an entirely new mosaic floor was laid.

The first case can probably be found in the reception hall (aula) of domus episcopalis (Fig. 1, no. 2). This hall is assumed to have received its mosaic floor in the $80^{\prime}$ 's of $4^{\text {th }} \mathrm{c}$. CE, which is characterized by the presence of two main images: the personification of Eirene, which gives the name of the building itself in modern archaeological literature (domus Eirene); and a cantharos (Fig. 19). The iconography is debated in numerous studies (Bospachieva 2003: 86-103; Pillinger et al. 2016: 174-198; and most recently in Topalilov 2018: 273-285).

Over the next centuries until the end of $6^{\text {th }} \mathrm{c}$. CE, it seems that the mosaic floor underwent several alterations linked with the change of the functions of the room (Pillinger et al. 2016: 197; Topalilov 2018: 273-285). The building continued to exist as domus episcopalis, probably at least until $586 \mathrm{CE}$, when the greater part of Philippopolis in the plain was left extra moenia, and therefore in the hands of the Avars that besieged the city and possibly destroyed the existing complexes. A coin of Phocas (602-610 CE) was found on the mosaic floor at domus Eirene (Bospachieva 2003: 102) indicating that there was some form of habitation at the time, but we cannot assume that the building was restored on the scale of middle of $5^{\text {th }} \mathrm{c}$. CE.

During these centuries, it seems that the borders of the mosaic floor have also undergone some alterations. In order to reveal them, a note should be made on the frames of the mosaic under consideration. Given the iconographic parallels with other mosaics in Thrace, in particular those in the neighboring center of Augusta Trajana (Pillinger et al. 2016: Taf. 73 Abb. 204), as well as the colour scheme and iconographic features used, we can assume that the southern border consisted of two different panels followed by three consecutive lines in white, black, and yellow (Fig. 19). Only half of this initial border is preserved in the western half of the southern border and partly in the western one (Fig. 20). As 
for the northern border, things are less clear, but it seems that only two panels of the initial border survived (Décor I: pl. 171, pl. 237a). Another repair is visible in the eastern half of the southern and the entire eastern border with the imposition of the band with leaves in black and white.
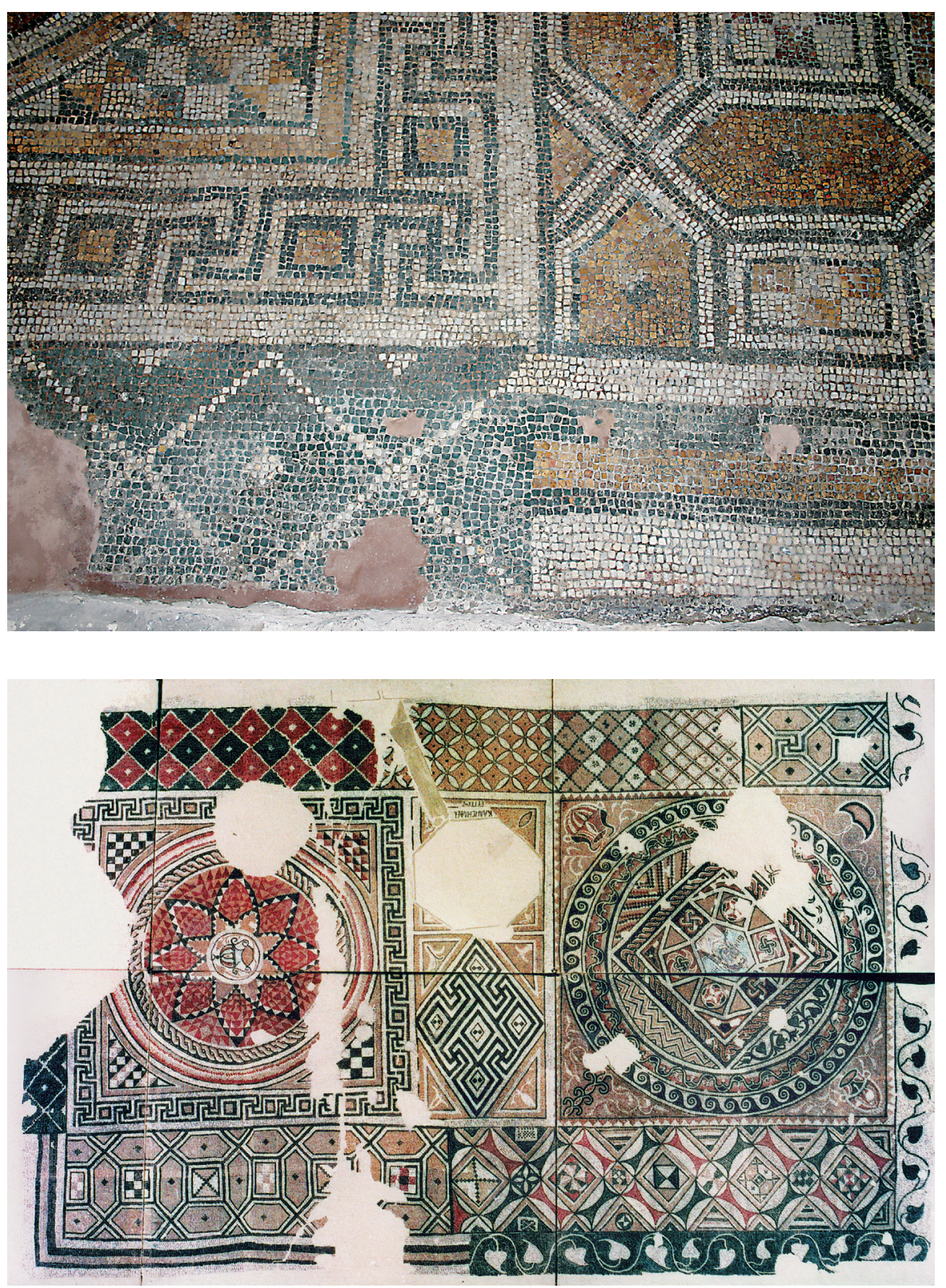

Another repair of this type might be found in the western border with the band filled with tangent squares and diamond in black and white (Décor I: pl. 15e). A similar repair is to be observed also in the western part of the northern border with three colours - black, white, and red (Fig. 21). They both differ significantly, not only with the specific iconographic scheme crudely executed and simple patterns such as the diamond when compared with the rest panels in the borders, but also in scarcity of colours. The second and third panels in the northern border may also be attributed to later repairs. Indeed, it is difficult to determine the individual corrections and their dates accordingly.
Figure 19

A fragment of the mosaic pavement of the aula (after Pillinger et al. 2016: Taf. 129 Abb. 336)

Figure 20

The mosaic pavement of the aula of domus episcopalis (domus Eirene) (after Pillinger et al. 2016: Taf. 120 Abb. 319). 
Figure 21

A fragment of the mosaic pavement of the aula (after Pillinger et al. 2016: Taf. 129 Abb. 337).

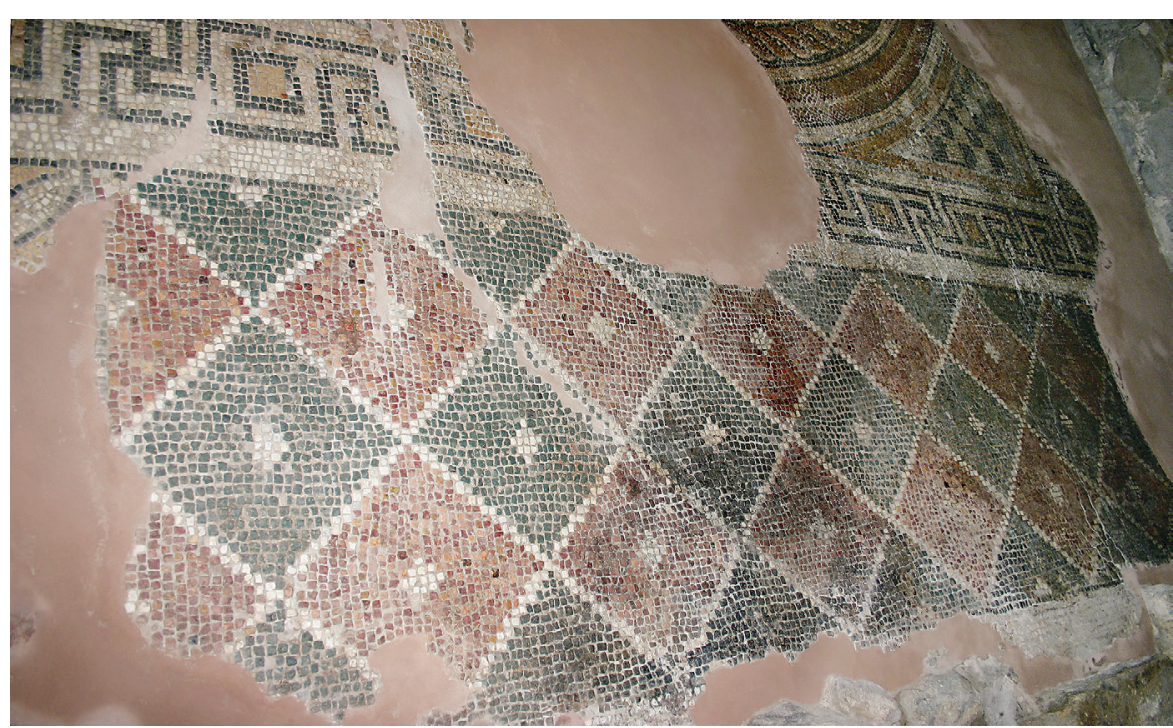

Certain repairs are made after the building was damaged, though not dramatically, during the Hunnic invasions in 40's of $5^{\text {th }} \mathrm{c}$. CE (Bospachieva 2003: 102). The large difference in craftsmanship and colours, however, when compared to the rest of the mosaic pavements in domus Eirene as well as those in the Episcopal Basilica of the third quarter of $5^{\text {th }}$ c. CE (Pillinger et al. 2016: Taf. $155 \mathrm{Abb} .402$ ) and the suburban monastery (?) located near the "Eastern gate" complex (Pillinger et al. 2016: Taf. 184 Abb. 473), allows us to assume that at least the western border and the western half of the northern border of the aula of the domus episcopalis should be dated to $6^{\text {th }} \mathrm{c}$. CE. The restoration of the representative part of the complex suggests that the building preserved its importance at that time.

It seems that in $6^{\text {th }} \mathrm{c}$. CE, the domus episcopalis was not the only private building, if it can be considered as such at all, that received new mosaic decoration. Thus, the so-called "apodyterum" in the residential complex, located west of the Episcopal Basilica, also received its mosaic decoration at that time (Fig. 1 no.3). It was made by large, irregularly cut tesserae with polychrome border, which consists of tendril with blue-green and dark red ivy leaves, while the panel itself is filled with circles interlooped tangentially, forming circle medallions and irregular concave octagons (Décor I: pl. 235a). The medallions contain the images of vessels, animals (birds, fish, a horse), fruits and other individual motifs such as a birdcage and anthropomorphic head (mask?) etc. The concave octagons are filled with stylized rosettes. In fact, all of the images, figural or organic, are very stylized, which is one of the main features of the mosaic pavement, along with the diversity of images. While the range of colours is not limited (red, blue, yellow, brown, white, pink, etc., are all present), vivid colours are not dominant (Fig. 22). Initially, the mosaic is dated roughly to $5^{\text {th }}-6^{\text {th }} \mathrm{c}$. CE, but recently is refined to second half of $5^{\text {th }} \mathrm{c}$. CE (Pillinger et al. 2016: 173).

Indeed, in the recently published Corpus of Late antique and Early Christian mosaic pavements in Bulgaria, the parallels suggested for this mosaic are dated to the first half of $5^{\text {th }} \mathrm{c}$. CE (Pillinger et al. 2016: 173), but they could be hardly recognized as exact parallels. This could be applied to the geometric scheme, but also the filling motifs, range of colours, and the iconography itself. A brief review of the specifics of these parallels will make this clear. For example, if we consider the mosaic in the central nave of the basilica in Odessos, which is taken as a comparandum, one would note the difference in colours as well as 


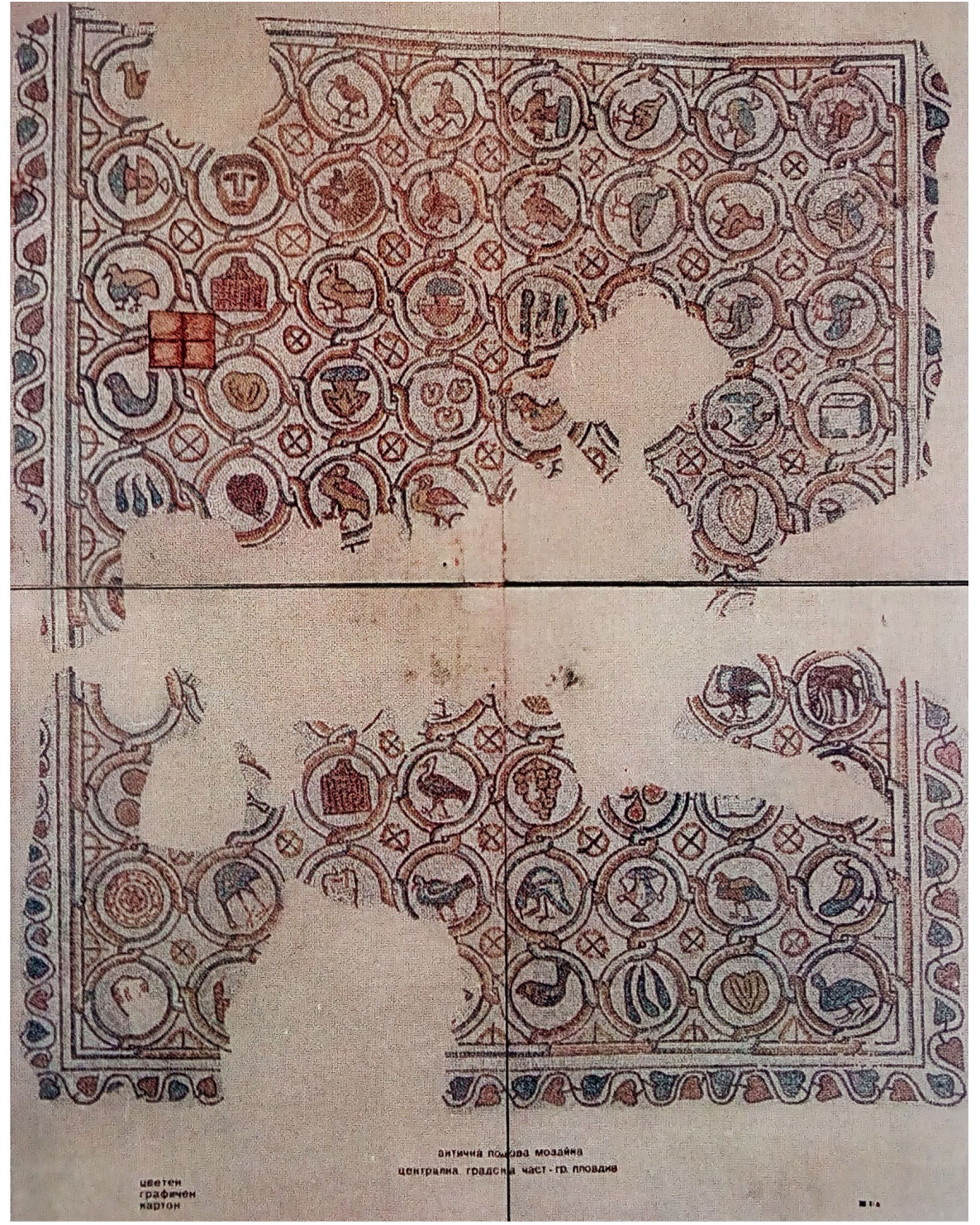

filling motifs, in both medallions and concave octagons (Pillinger et al. 2016: Taf. 9 Abb. 17). In fact, beyond the geometric scheme, no additional similarities could be found between the two mosaics. A major difference can be found also between the mosaic in Philippopolis and that in the narthex of the basilica at Škorpilovci. Indeed, the geometric scheme is equal, and the medallions are filled with animals, birds, plants and objects, including vases, and most figures are accompanied by one or two branches with flowers or birds (Pillinger et al. 2016: 49-50 Taf. 20 Abb. 50), but these are all the similarities between the mosaics. The differences, however are numerous and include: the motifs in the border; the frame of the panel; the medallions which are made by shaded band and with guilloche; the stylized fillings of the octagons of the first row; and the colour range. Besides, the mosaic in Philippopolis is highly stylized in every aspect, including the bands.

More similar to the mosaic in Škorpilovci, rather to that in Philippopolis, is the mosaic which decorated the southern room of the narthex of basilica 1 in Kabile, although large differences are attested too. The similarities are to be found mainly in the fillings of the frame that form the medallions and concave octagons, executed, however, in different colours. The rest of the mosaic is totally different, especially in relation with the border and the entirely geometric
Figure 22

The mosaic pavement of the so-called "apodyterium" (after Pillinger et al. 2016: Taf. 117 Abb. 314). 
Figure 23

The bordure of the second panel in the nave of the Episcopal basilica (archive of E. Kessjakova). filling of the medallions and octagons. The mosaic seems more colour saturated, and the motifs and geometric forms are more elaborate (Pillinger et al. 2016: Taf. 63 Abb. 181; Taf. 64-65 Abb. 182-187).

I would not use the mosaic panel in the so-called Basilica (no. 7) brought to light in Pautalia, an extra muros basilica, dated to the second half of $5^{\text {th }} \mathrm{c}$. CE as an explicit parallel as suggested (Pillinger et al. 2016: Taf. 348-350 Abb. 854-862). The border, geometric frames, various fillings of the medallions and octagons, including the fons vitae, rich colour palette of fresh, lively, and yet finely coordinated shades, as well as manner of drawing and developed style are in sharp contrast to the mosaic in Philippopolis.

This short review reveals that, although some similarities between the mosaics discussed and that in Philippopolis may be found, there are prevalent differences in the motifs used, colours, style and manner of execution, and even in some cases in the bands that compose the geometric scheme. What united all the examples cited is the geometric scheme. Yet, unlike the stylized shaded bands used in Philippopolis, the aforementioned parallels present the combination of shaded bands and guilloche, as the image is more elaborated.

I believe that the closest parallel to our mosaic may be found in Philippopolis itself, in the central nave of the Episcopal Basilica. The resemblance can be found in every part of the decoration - partly in the border, geometric scheme and its bands, the filling motifs as well as the colours. For instance, the border decoration with such leaves orientation is specific, as such pattern could not be found elsewhere in the metropolis so far, but just in the border that encircles the second panel in the nave (Fig. 23). Indeed, a change can be observed in the colours that filled the leaves, but this has an explanation and will be discussed below. A slight change can also be observed in the decoration of the band that forms the geometric scheme, with the replacement of the yellow by light blue in

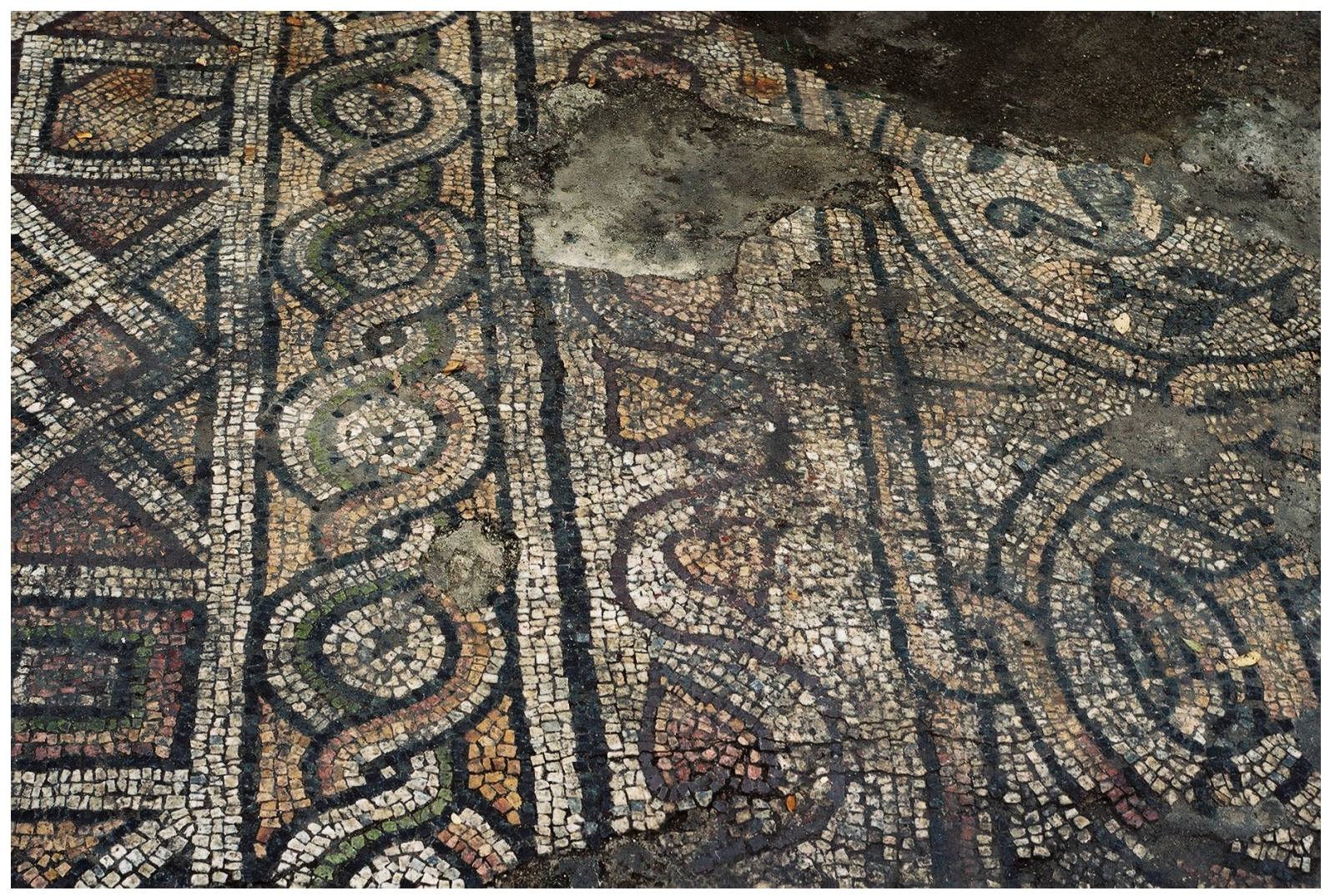




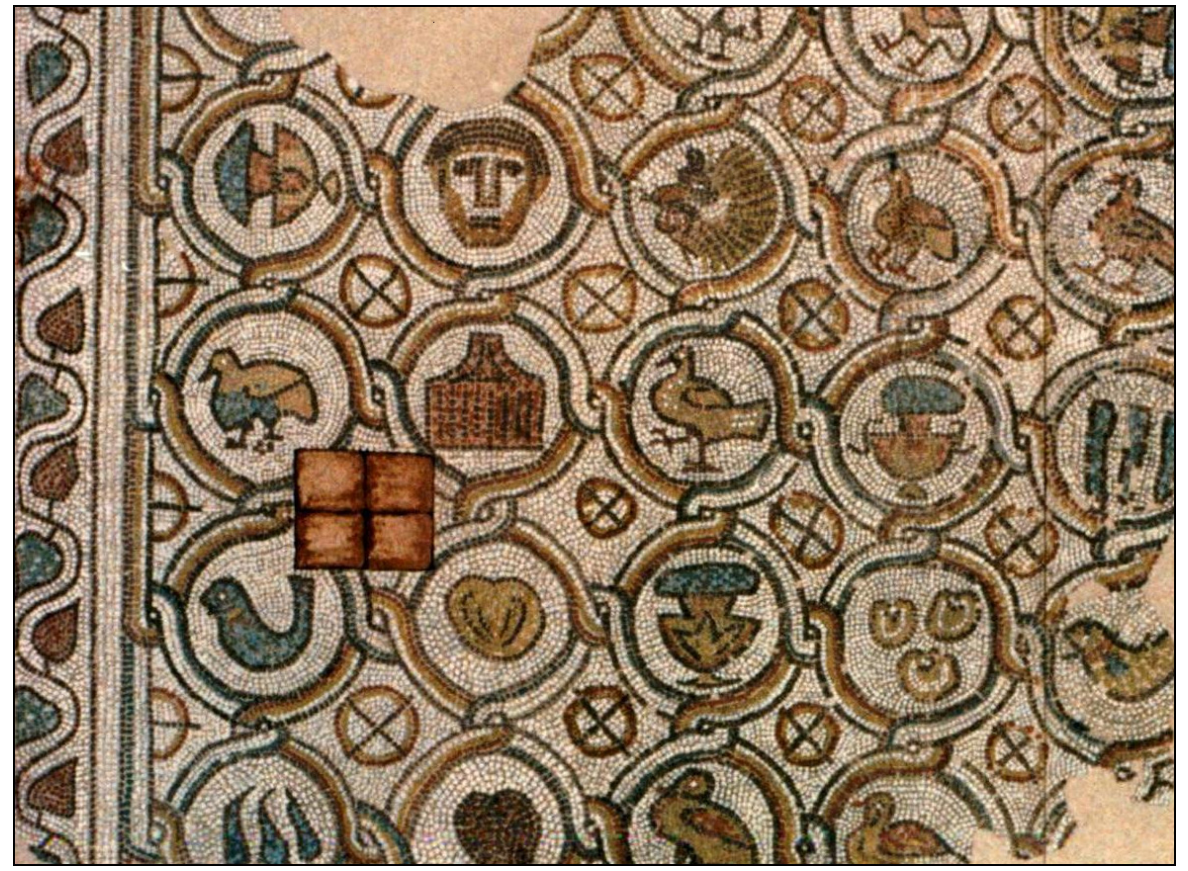

the single shaded band, but the underlying silhouette remains (Fig. 24). Besides, most of the filling motifs in both examples overlapped. All of these similarities reveal that both mosaics are more connected than has been presumed so far, with the one being the prototype of the other.

It is suggested in the literature that in some private residential complexes in Philippopolis mosaic decoration in fact copies partly the mosaic decoration of the public buildings. The examples so far are mostly concentrated on the borders. Indeed, there are some discrepancies in the accuracy, manner and stylistics, but they might be due to the workmanship and abilities of local workshop. This shows that in these cases it is not about traveling craftsmen, but production of local workshop (Topalilov 2016a: 183-188). In our case, it seems that the border iconography copied that of the second panel of the nave of the Episcopal basilica, but the colour range with blue and red follows a mosaic pavement in another Christian building - that of the suburban monastery (?) located near the "Eastern gate" complex of the city (Pillinger et al. 2016: Taf. 184 Abb. 473).

If all this is correct, it seems the mosaic decoration of the so-called "apodyterium" under discussion is mainly a combination of the decoration of the first two panels of the nave of the Episcopal Basilica with the border of the suburban monastery (?). What is striking is that it was whole panels with various motifs used, such as birds with and without plant, vases, bucket with fruits, peacock with full feathers, some obscure objects such as the spoons for example, etc., that formed the iconography and were copied entirely. One may note, however, that the private mosaic is much more diverse, with other types of image added. For instance, besides the various birds, some animals are also introduced, including fish. Some of them may be found in other places in Philippopolis, as it shows that case with bird presented with head down stepping on the globe (?) which can be found in the same posture in the mosaic pavement that decorated the room with the apse of another residential complex located in the neighborhood; the construction of the latter is dated to first half of $4^{\text {th }} \mathrm{c}$. CE (Pillinger et al. 2016: 164-169 Taf. $114 \mathrm{Abb}$. 307). If this earlier mosaic is the prototype, the image in the so-called "apodyterium" may reveal what the original bird looks like. Besides, the blue into which the bird is presented is among the main colours used in the earlier
Figure 24

A fragment of the mosaic pavement of the so-called "apodyterium" (after Bospachieva - Kolarova 2014: 286). 
Figure 25

A fragment of the mosaic pavement of the so-called "apodyterium". mosaic, too. The image of the hind or deer with head down can find parallel with the image of the deer in the same position at the baptistery added to the so-called "Small basilica" (Pillinger et al. 2016: Taf. 172 Abb. 445). Of interest are also the images of the various vessels, including crater and cantharos, all of them filled with water as suggested by the blue tesserae on the mouth, which in some cases is linked to the Fountain of Life (fons vitae)(more examples and discussion in Popova 2016: 154-198). As for the colour range of the border, it is plausible to suggest that the mosaic of the so-called "apodyterium" followed that in the suburban monastery (?) (Pillinger et al. 2016: Taf. 184 Abb. 473). All this allows us to assume that at the bottom of the mosaic pavement of the "apodyterium" lie the eastern two panels of the central nave of the Episcopal basilica, with other motifs that were taken from the decoration of other private houses and Christian buildings in Philippopolis or invented by the owner of the residential complex. Some of the motifs, such as the mask, for example, may have originated from pagan mosaics expressing specific ideas that spread among the aristocracy in that time. This is why the mosaic under question combines symbols that were used in Early Christian art, but also items from everyday life. If so, given the very stylized images and the huge differences in accuracy (Fig. 25), the date

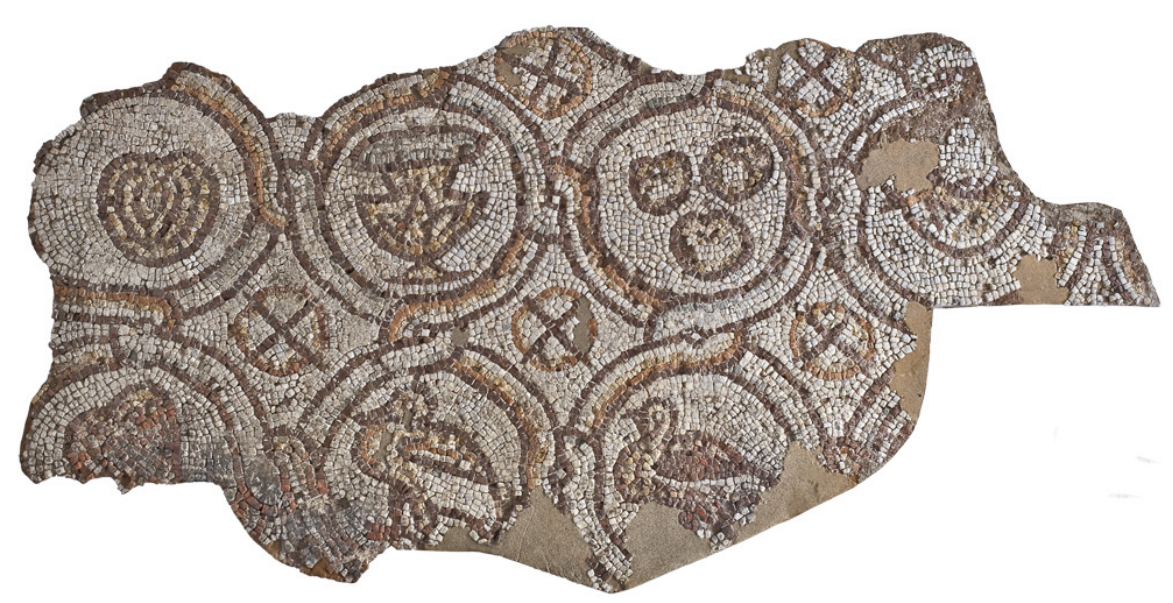

of the eastern panel of the central nave of the Episcopal Basilica would give a possible terminus post quem for the mosaic in the "apodyterium". Therefore, I am inclined to date that mosaic pavement after the mosaics in the Episcopal Basilica and the Christian temple that replaced the synagogue.

After this short review of the mosaic pavements that could be dated to $6^{\text {th }} \mathrm{c}$. $\mathrm{CE}$ in Philippopolis, I offer some preliminary conclusions. Mosaic decoration was in fact an essential part of $6^{\text {th }} \mathrm{c}$. CE decoration in the city, albeit not on such a great scale as in the second half of $5^{\text {th }} \mathrm{c}$. CE, when the metropolis was restored. Although on attested on a lesser scale, mosaic production can be found in some form in every type of building, public and private. The basilicas and the conch martyrium, although religious structures, give good examples for the new mosaic trend revealed in the public buildings. On the other hand, if the residential complexes, including the domus episcopalis, were assigned to this group, they would reveal the spread of the mosaic floor decoration in the private space. While the new mosaics could be considered as just a repair of earlier mosaic floors, they also could cover the whole floor or an important part of it. The case in the Episcopal basilica is indicative, as in fact the intervention by inserting new panels around the presbyterium may be due to new liturgical requirements 
introduced by Constantinople in the metropolis and main urban centers in the province of Thrace. This case clearly reveals that that in Philippopolis in $6^{\text {th }} \mathrm{c}$. $\mathrm{CE}$ mosaic pavement was still a very important, if not the most, medium for addressing such developments.

When we are dealing with the mosaic decoration of the religious buildings in Philippopolis, the conch martyrium is of great interest. If the mosaic pavement is as late as proposed, it should be among the latest mosaic floors produced in Late antique Philippopolis and possibly Thrace. The decoration is of interest as it combines various symbolic features that obviously had been taken from other buildings, and followed the trend in the mosaic development of a colourful dichotomy between border and inner field. This mosaic is the only one of this type found so far in Philippopolis and therefore of great importance as we are aware that this feature is particularly common in the Near East, and especially Syria (see for instance Dauphin - Edelstein 1993: 51, 52, pl. II c; Gazit - Lender 1993: 275 etc.; Magen 1993: 179). No doubt, its appearance could shed some light on the spread of iconographic ideas in $6^{\text {th }} \mathrm{c}$. CE, in this case from the Near East to the Balkans. As this trend gained wide acceptance in the middle of $6^{\text {th }}$ c. CE, I would not hesitate to date the embellishment of the conch martyrium with mosaic pavement into the time of Justinian I. I confess that the proposed date seems to be rather late given the fact that we are dealing with the main martyrium in Philippopolis, possibly one of the most important in the province, and, as such, it is highly improbable that it remained undecorated until that time. The only other explanation is that the mosaic floor has an earlier date, perhaps in the second half of $5^{\text {th }} \mathrm{c}$. CE, and the combination of various motifs and ideas originating from other buildings, not only in Philippopolis, makes it unusual. Anyway, I believe that the liturgical needs and changes are also implemented in the mosaic decoration as it was in the Episcopal basilica. Whether these changes are a result of the same liturgical initiative remains unclear.

It seems that mosaic decoration in the public Christian buildings might have inspired the rich owners of the residential complexes in Philippopolis to embellish their private space in similar fashion. Indeed, the tradition of copying the decoration of the public buildings is not new in Philippopolis, but in $6^{\text {th }} \mathrm{c}$. $\mathrm{CE}$ it did not just gain wide acceptance, but it was the only one possible practice due to practical reasons; the Christian buildings were the most important, imposing, and embellished in the city in that time. As already observed, it was not, however, a full copy of the basilica mosaic decoration that was made, but some new specific motifs were also added, some of them unknown so far in the mosaic art in the city and atypical for Christianity. This is how we can explain some peculiar objects in the mosaic floor of the so-called "apodyterium" of the residential complex discussed above. With the image of the mask, one can go further in searching for personal grounds in some of the motifs, linked with the theater and artistic life, but also as a sign of belonging to the civic elite of the metropolis, or at least to a certain group of it. The whole decoration and the various motifs do not imply a certain Christian symbolism. This mosaic is also of interest as it reveals the mechanism by which the main conception of the mosaic content was composed by the owner of the building - using the border and geometric scheme from leading Christian buildings such as the Episcopal basilica and suburban monastery (?) whose decoration obviously led the fashion at that time, with some other, uncommon motifs added that show his own taste. While this practice is not new and may be observed in other earlier mosaic pavements in Philippopolis, it may explain the unique decoration of the mosaic itself. 
The mosaic decoration of the "apodyterium" is also of interest because to me it undoubtedly shows the existence of a local mosaic workshop at that time. The simplicity of the patters and their crude execution in terms of the schematism and stylization may be distinctive characteristics for this workshop in late Justinianic and post-Justinianic time, if this is the date of the mosaic pavement. In fact, by its manner of stylization, this mosaic differs significantly from the rest of the mosaic pavements in Late antique Philippopolis and, as it is the only one of this type, I believe that it is a production of a local workshop that worked only for a short span of time.

The short analysis of the mosaic decoration in $6^{\text {th }} \mathrm{c}$. CE Philippopolis does not allow us to conclude that a certain embellishment program of all the buildings in the time of Justinian in Philippopolis was executed. With only one exception, though important, that of the martyrium, we have no other sure evidence of such activity. This may be due to the fact that the standing Christian basilicas already had mosaic pavements and there was no need for this. It seems that the only need in that time was to maintain the large mosaic floors and to insert new panels as a result of the new liturgical requirements. It seems, however, that the mosaic decoration preserved its importance as revealed by the early Christian tomb that was located most probably in the Eastern necropolis, decorated with mosaic floor. It should be underlined that although the liturgical initiative in both the Episcopal basilica and conch martyrium reflected in the mosaic decoration came from the imperial capital, it seems that the execution in Philippopolis was in the hands of locals, using the local mosaic workshop; the lack of any "pseudoemblema" and inscriptions specific to the Justinianic period are arguments for this conclusion.

It seems that some of the activity attested in the field of mosaic decoration in $6^{\text {th }} \mathrm{c}$. CE in Philippopolis may also be applied to pre-Justinianic time. During the reign of Anastasius I the synagogue was turned into a Christian temple and received new mosaic pavement. The latter still follows the traditions of the mosaics of second half of $5^{\text {th }} \mathrm{c}$. CE, with the avoidance of figural motifs. In fact, the vivid and extensive colour range is the main detail that differentiates that mosaic from those in the $4^{\text {th }} \mathrm{c}$. CE. Hence, I would not hesitate to assume that the mosaic decoration of the new Christian temple was produced again by the local workshop in Philippopolis and followed some earlier Christian examples in the city.

The analysis proposed is preliminary; some points and proposed dates require further argument. In spite of this, however, it reveals an aspect of the urban development of the metropolis of the province of Thrace that has escaped up to now the attention of scholars. As the urban development of Philippopolis in $6^{\text {th }} \mathrm{c}$. CE has not gained much attention in specific studies, many details and problems, especially those of the Anastasian and Justinianic city, remain unclear and unresolved. With this study, I hope to have filled some part of this gap, although it is confined within the limits of the development of mosaic art only. 


\section{Bibliography - Kaynaklar}

Anna Comnenae Alexias

Bospachieva 2002

Bospachieva 2003

Bospachieva - Kolarova 2014

Bospačieva 2001

Bospatchieva 2001

Chaneva-Dechevska 1999

Dauphin - Edelstein 1993

Décor I

Dinchev 2009

Dyakovich 1906/1907

Gazit - Lender 1993

Kantareva-Decheva 2017

Kesjakova 1983

Kesjakova 1989

Kesjakova 1989a

Kesjakova 2006

Kesjakova 2011

Kolarik 2014

Magen 1993

Pillinger et al. 2016

Popova 2016

Proc. Libri de bellis. VIII

\section{SGLIBulg}

Theop. Sim. Hist., VIII.

Theoph. Confess. Chron.

Topalilov 2012

Topalilov 2012a
Annae Comnenae Porphyrogenitae Alexias, rec. A. Reifferscheir, Lipsiae, 1884

M. Bospachieva, "A small early Christian basilica with mosaics at Philippopolis”, ABulg 2, 55-76.

M. Bospachieva, "The Late Antiquity building EIPHNH with mosaics from Philippopolis (Plovdiv, Southern Bulgaria)", ABulg 2, 83-105.

4 M. Bospacheiva - V. Kolarova, Plovdiv - grad varhu gradovete, Filipopol - Pulpudeva - Paldin, Sofia.

M. Bospačieva, "Die "äußere” Festungsmauer von Philippopolis im Licht der jüngsten archäologischen Untersuchungen”, M. Wendel (ed.), Karasura Vol. 1. Untersuchungen zur Geschichte und Kultur des alten Thrakien (Weissbach), 173-183.

M. Bospatchieva, “An Early Christian Martyrium from Philippopolis”, ABulg 2, 59-69.

N. Chaneva-Dechevska, Rannohristiyanskata arhitektura v Balgariya IV-VI, Sofia.

C. Dauphin - G. Edelstein, "The Byzantine Church at Nahariya", Y. Tsafrir (ed.), Ancient Churches Revealed, Israel Exploration Society, Jerusalem, 49-53.

C. Balmelle - M. Blanchard Lemée - J.Christophe - J.-P. Darmon - A.-M. Guimier Sorbets - H. Lavagne - R. Prudhomme - H. Stern, Le Décor Géométrique de la Mosaïque Romaine I, Paris, 1985.

V. Dinchev, "Antichnite gradski ploshtadni kompleksi i tyahnata sudba prez kusnata antichnost. Chast 1. Philippopolis i Nicopolis ad Istrum”, B. Petrunova - A. Aladžov - E. Vasileva (eds.), LAUREA. In honorem Margaritae Vaklinova Vol. 1, Sofia, 63-81.

B. Dyakovich, "Trakiiska grobnitza pri Plovdiv i nekropolat na drevnija grad”, Sbornik za narodni umotvorenija, nauka i knizhnina, XXII/XXIII, 1-55.

D. Gazit - Y. Lender, "The Church of St. Stephen at Horvat Be'er-shem 'a”, Y. Tsafrir (ed.), Ancient Churches Revealed, Israel Exploration Society, Jerusalem, 273-276.

E. Kantareva-Decheva, "Novi stratigrafski prouchvanija na mozaikata ot Episkopskata bazilika na Filipopol”, T. Shekerdzhieva-Novak (ed.), Sbornik dokladi ot Mezhdunarodna nauchna konferentsiya "Nauka, obrazovanie i inovatsii v oblastta na izkustvoto", Plovdiv, 365-372.

E. Kesjakova, “Akveduktite i vodosnabdyavaneto na Filipopol”, Archeologiya 1-2, 63-76.

E. Kesjakova, “Antichna sinagoga vav Filipopol”, Arheologiya 1, 20-33.

E. Kesjakova, “Rannohristiyanska bazilika ot Filipopol”, IzvMuzJužBalg 15, 113-127.

E. Kesjakova, "Za rannohristiyanskata arhitektura na Filipopol”, A. Dimitrova-Milcheva - V. Kazarova (eds.), Spartacus II, Veliko Turnovo, 146-156.

E. Kesjakova, "Mozaiki ot episkopskata bazilika na Filipopol”, St. Stanev - V. Grigorov - V. Dimitrov (eds.), Studies in honour of Stefan Boyadzhiev, Sofia, 173-210.

R. Kolarik, "Synagogue Floors from the Balkans: Religious and Historical Implications", M. Rakocija (ed.), Niš and Byzantium, 12, 115-128.

Y. Magen, "The Monastery of St. Martyrius at Ma'ale Adummim”, Y. Tsafrir (ed.), Ancient Churches Revealed, Israel Exploration Society, Jerusalem, 170-196.

R. Pillinger - A. Lirsch - V. Popova (Hg.). Corpus der spätantiken und frühchristlichen Mosaiken Bulgariens, Wien.

V. Popova, "Fons Vitae in Late Antique monuments in Bulgaria", Studia academica Šumenensia 3, 154198.

Procopius, Libri de bellis, Ed. by Haury, Jakob / Wirth, Gerhard, Bibliotheca scriptorum Graecorum et Romanorum Teubneriana, De Gruyter, 2013.

V. Beševliev, Spätgriechische und spätlateinische Inschriften aus Bulgarien, Berlin, 1964.

Theophylacti Simocattae, Historiae, ed. C. de Boor, Lipsiae 1887.

Theophanis Chronographia, ed. C. de Boor, Lipsiae, 1883.

I. Topalilov, Das Römische Philippopolis. Band 1. Topografie, städtebau und architektur, Faber, Veliko Turnovo.

I. Topalilov, "Philippopolis during I - beginning of VII c.”, R. Ivanov (ed.), The Roman and Late Roman 
Topalilov 2014

Topalilov 2014a

Topalilov 2016

Topalilov 2016a

Topalilov 2016b

Topalilov 2018

Topalilov 2019

Topalilov 2020

Topalilov - Ljubenova 2010

Westphalen 2016 cities in Bulgaria, Vol. 1, Sofia, 363-437.

I. Topalilov, "The Barbarians and the city: A case study on the impact of the barbarian invasion from AD 376378 and AD 442-447 on the urbanism of Philippopolis, Thrace”, K. Parry - D. Dzino, (eds.), Byzantium and Neighbors. Byzantina Australiensia, Vol. 20, 223-244.

I. Topalilov, "Barbarians and Philippopolis, Thrace, in the second half of the $6^{\text {th }}$ century (on archaeological data)", Studia academica Šumenensia 1, 94-113.

I. Topalilov, "The impact of the religious policy of Theodosius the Great on the urbanization of Philippopolis, Thrace (Preliminary notes)", O. Brandt - V. Fiocchi Nicolai, (eds.), Costantino e i Costantinidi: l' innovazione costantiniana, le sue radici e i suoi sviluppi, Acta XVI Congressus Internationalis Archaeologiae Christianae, Roma, 22-28.09.2013, Città del Vaticano: Pontificio Istituto di Archeologia Cristiana, 1853-1862.

I. Topalilov, "Local Mosaic Workshops in Late Antique Philippopolis, Thrace: Some consideration”, L. Neira Jiménes (ed.) Estudios sobre mosaicos antiquos y medievales, Madrid, 183-188.

I. Topalilov, "The importance of the so-called 'Eastern Gate' complex for the Christians and Christianity in LA Philippopolis", M. Rakocija (ed.), Cities and Citizens in Byzantine World. Niš and Byzantium 14, 265-274.

I. Topalilov, “On the Eirene mosaic from Philippopolis, Thrace”, JMR 11, 273-285.

I. Topalilov, "The Early Christian basilicae in Philippopolis and Herakleia - two pieces of work of an unknown metropolitan mosaic workshop" (in Print).

I. Topalilov, "Porta Triumphalis v Kasnoantichna Trakija”, N. Kanev (ed.) Ruler, State and Church on the Balkans in the middle ages. In honour of the $60^{\text {th }}$ anniversary of Professor Dr. Plamen Pavlov, Vol. 1, Veliko Tarnovo, 304-324.

I. Topalilov - A. Ljubenova, "Neue Uberlegungen zum hexakonchalen Martyrium von Philippopolis (Plovdiv, Bulgarien)", MitChrA 16, 69-79.

St. Westphalen, Die Basilica am Kalekapı in Herakleia/ Perinthos. Bericht über die Ausgrabungen von 19922010 in Marmara Ereğlisi, IstForsch 55. 
